\title{
Alternative Conceptual Approach to the Design of Bifunctional Catalysts: An Osmium Germylene System for the Dehydrogenation of Formic Acid
}

María L. Buil, Javier A. Cabeza, Miguel A. Esteruelas,* Susana Izquierdo, Carlos J. Laglera-Gándara, Antonio I. Nicasio, and Enrique Oñate

Cite This: Inorg. Chem. 2021, 60, 16860-16870

Read Online

ABSTRACT: The reaction of the hexahydride $\mathrm{OsH}_{6}\left(\mathrm{P}^{\mathrm{i}} \mathrm{Pr}_{3}\right)_{2}$ with a $\mathrm{P}, \mathrm{Ge}, \mathrm{P}-$ germylene-diphosphine affords an osmium tetrahydride derivative bearing a $\mathrm{Ge}, \mathrm{P}$-chelate, which arises from the hydrogenolysis of a $\mathrm{P}-\mathrm{C}\left(\mathrm{sp}^{3}\right)$ bond. This $\mathrm{Os}(\mathrm{IV})-\mathrm{Ge}$ (II) compound is a pioneering example of a bifunctional catalyst based on the coordination of a $\sigma$-donor acid, which is active in the dehydrogenation of formic acid to $\mathrm{H}_{2}$ and $\mathrm{CO}_{2}$. The kinetics of the dehydrogenation, the characterization of the resting state of the catalysis, and DFT calculations point out that the hydrogen formation (the fast stage) exclusively occurs on the coordination sphere of the basic metal center, whereas both the metal center and the $\sigma$-donor Lewis acid cooperatively participate in the $\mathrm{CO}_{2}$ release (the rate-determining step). During the process, the formate group pivots around the germanium to approach its hydrogen atom to the

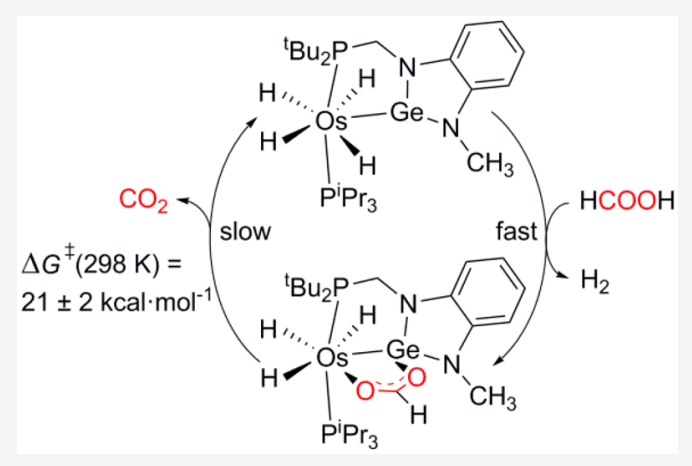
osmium center, which allows its transfer to the metal and the $\mathrm{CO}_{2}$ release.

\section{INTRODUCTION}

The direct participation of both the metal center and a ligand of the catalyst during a transition-metal-catalyzed organic transformation is a successfully employed strategy in the current homogeneous organometallic catalysis. The metalligand cooperation is based on the distribution of roles among the main actors of the catalyst. In most of the cases, the metal acts as a Lewis acid whereas the ligand is a Lewis base ( $\mathbf{a}$ in Chart 1). ${ }^{1}$ Such a principle is the support of most relevant

Chart 1. Bifunctional-Type Catalysts

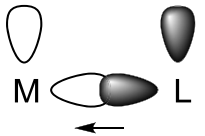

a) Traditional

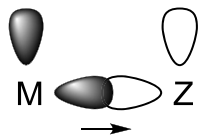

b) $M \rightarrow Z$ interaction

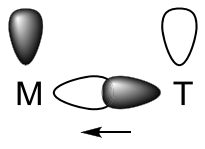

c) This work catalysts of this class, including Shvo's cyclopentadienone metal complexes, ${ }^{2}$ Fujita's iridium pyridonate, ${ }^{3}$ NoyoriIkariya's ruthenium amide, ${ }^{4}$ or Milstein's PNN-metal systems. ${ }^{5}$ Nevertheless, the design of bifunctional catalysts to operate with exchanged metal-ligand roles has awakening great interest in the last few years. ${ }^{6}$ Such catalysts are formed by a basic metal and an acidic $\sigma$-acceptor Z-type ligand where the bonding $\sigma$-orbital is empty (b in Chart 1$){ }^{7}$ Unfortunately, the number of Z-type ligands is notably limited ${ }^{8}$ and as a consequence the reactions employing catalysts of this class are still very scarce. Metal Lewis bases mainly involve $3 \mathrm{~d}$ metals, with iron, ${ }^{9}$ cobalt $^{10}$ and nickel $^{11}$ in prominent positions, in addition to rhodium, ${ }^{12}$ palladium, ${ }^{13}$ platinum, ${ }^{14}$ and gold. ${ }^{15}$ The Lewis acid site of the ligands is boron $^{9,10 a-c, 11 b-d, 13 a, 15 b, d}$ in the great majority of the cases and to a much lesser extent aluminum, ${ }^{115 a}$ gallium, ${ }^{11 \mathrm{e} 11 \mathrm{f}}$ indium, $^{12}$ silicon, ${ }^{13 \mathrm{~b}}$ and antimony. ${ }^{7 \mathrm{~b}, 14,15 \mathrm{c}}$ Catalytic reactions include oligomerization of primary silanes, ${ }^{11 a}$ sila-Negishi couplings, ${ }^{13 \mathrm{~b}}$ hydrosilylation of aldehydes, ${ }^{10 \mathrm{c} 11 \mathrm{c}}$ olefin and alkyne hydrogenations, ${ }^{9,11 \mathrm{~b}, \mathrm{~d}, \mathrm{f}} \mathrm{CO}_{2}$ hydrogenation to formate, ${ }^{11 \mathrm{e}}$ amine-borane dehydrogenation, ${ }^{10 \mathrm{a}, \mathrm{b}}$ cycloisomerization of propargylamides, ${ }^{15 a}$ hydroaminations, ${ }^{15 c, d} \mathrm{C}-\mathrm{H}$ amination, ${ }^{12}$ enyne cyclization, ${ }^{14,15 \mathrm{~b}}$ and dehalogenation of aryl chlorides. $^{13 a}$

The electron density flow of the metal-ligand interaction in both classes of bifunctional catalysts goes from the Lewis base to the Lewis acid, as usual. However, that works against the nature of both, since it decreases the basicity of the former and the acidity of the latter. We now address an alternative

Received: September 16, 2021

Published: October 16, 2021 
approach ( $\mathrm{c}$ in Chart 1): the assembly of a bifunctional catalyst carrying such a flow in favor of both actors, enhancing the basicity of the base and the acidity of the acid. The challenge needed a basic center able of accepting electron density from an acidic center capable of donating it. We reasoned that such a situation would be possible by means of the use of a basic metal center, which should be in a high oxidation state, in contrast to those employed in catalysts involving a $\mathrm{M} \rightarrow \mathrm{Z}$ interaction. The high oxidation state should favor the acceptance of electron density from a $\sigma$-donor orbital and prevent significant back-bonding donation to an empty $\pi$ orbital. Metal fragments with these characteristics are the polyhydrides of the platinum-group metals. ${ }^{16}$ Among them, the osmium polyhydrides occupy a predominant position due to their proven ability to catalyze interesting organic synthesis reactions, ${ }^{17}$ in addition to the dehydrogenation of liquid organic hydrogen carriers ${ }^{18}$ and boranes. ${ }^{19}$ Promising acidic ligands capable of donating $\sigma$-electron density to a platinumgroup metal in a high oxidation state are the heavier tetrylenes, $^{20}$ heavier counterparts of Fisher-type carbenes. They prefer to situate the two free electrons in an orbital with marked $s$ character, leaving a vacant orbital with high $p$ character at an orthogonal plane. The metal-tetrylene bonding interaction is significantly weaker than the metal-carbene interaction, and its strength decreases on going down group 14. Thus, germylenes are particularly interesting due to the center position of germanium in the group, which grants a reasonable $\sigma$-donor ability and a low $\pi$-acceptor capacity to them. ${ }^{21}$ The latter is evidenced by the marked tendency of these ligands to undergo inter- and intramolecular addition of $2 \mathrm{e}^{-}$donor groups. ${ }^{22}$

Formic acid is a polar molecule that is able of interacting with a polar $\mathrm{M}-\mathrm{L}$ bond. Furthermore, because it is an attractive member of the family denoted as liquid organic hydrogen carriers, due to its low toxicity and flammability and reasonable gravimetric and volumetric hydrogen content (4.4 wt $\%$ and $53.4 \mathrm{~g} / \mathrm{L}$, respectively), ${ }^{23}$ its dehydrogenation to $\mathrm{H}_{2}$ and $\mathrm{CO}_{2}$ is of great interest. The reaction is catalyzed by both homogeneous and heterogeneous systems, including bifunctional catalysts based on the traditional acidic-metal/basicligand approach. ${ }^{24}$ The catalysis is divided into two main stages: $\mathrm{H}_{2}$ formation and $\mathrm{CO}_{2}$ formation. ${ }^{25}$ A mechanistic feature of the traditional bifunctional catalysts is the participation of both the metal and the ligand in the $\mathrm{H}_{2}$ formation stage, whereas the $\mathrm{CO}_{2}$ formation exclusively takes place on the metal coordination sphere. ${ }^{26}$ Thus, the dehydrogenation of formic acid might be an ideal reaction to be used as a proof of concept validation for our hypothesis and also to analyze the mechanistic differences between the traditional bifunctional catalysis and that now designed.

This paper reports the preparation of a bifunctional catalyst for the dehydrogenation of formic acid, based on an osmium(IV) germylene cooperative system, which works in a manner different from that of the traditional catalysts of this class and represents a new conceptual approach to the design of bifunctional catalysts.

\section{RESULTS AND DISCUSSION}

Preparation of the Catalyst. In the search for a catalyst with a robust skeleton, which provides a strong base-acid interaction to the system, we introduced the germylene acid between two phosphine groups, with the initial idea of giving it the role of the central moiety of a neutral P,Ge,P-pincer ligand.
With this aim, we chose 1,3-bis(di-tert-butylphosphanylmethyl)-1,3-dihydro- $2 \lambda^{2}$-benzo[ $\left.d\right][1,3,2]$ diazagermole, because it had previously shown a notable versatility in platinum-groupmetal chemistry. ${ }^{27}$ With this molecule in hand, we selected the $\mathrm{d}^{2}$ hexahydride $\mathrm{OsH}_{6}\left(\mathrm{P}^{\mathrm{i}} \mathrm{Pr}_{3}\right)_{2}(\mathbf{1})$ as the metal precursor, as it had proven to be efficient for the preparation of the tetrahydride $\mathrm{OsH}_{4}\left\{\kappa^{3}-P, O, P-\left[\operatorname{xant}\left(\mathrm{P}^{\mathrm{i}} \mathrm{Pr}_{2}\right)_{2}\right]\right\}$ by the replacement of the triisopropylphosphines and a hydrogen molecule with the neutral P,O,P-pincer ligand 9,9-dimethyl-4,5-bis(diisopropylphosphino)xanthene. ${ }^{17 \mathrm{e}}$

Treatment of toluene solutions of 1 with 1.1 equiv of the $\mathrm{P}, \mathrm{Ge}, \mathrm{P}$-pincer, at $110^{\circ} \mathrm{C}$, for $18 \mathrm{~h}$ led to the coordination of the germylene moiety to the osmium center, as expected. However, the substitution of only one triisopropylphosphine ligand was observed, while the hydrogenolysis of the $\mathrm{CH}_{2}-$ $\mathrm{P}^{\mathrm{t}} \mathrm{Bu}_{2}$ bond of one of the pincer side arms took place. As a result, di-tert-butylphosphine and the tetrahydride 2 , bearing one of the initial triisopropylphosphines and a Ge,P-chelating germylene-phosphine ligand, were formed (Scheme 1). The

\section{Scheme 1. Formation of 2}

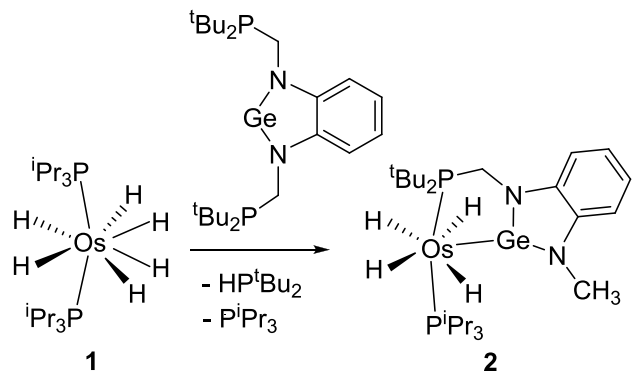

elimination of di-tert-butylphosphine from the original $\mathrm{P}, \mathrm{Ge}, \mathrm{P}$ pincer is notable. In spite of it being argued as the reason for the degradation of some hydrogenation catalysts ${ }^{28}$ and of being known for the rupture of $\mathrm{P}-\mathrm{C}$ bonds of some quaternary phosphonium salts under catalytic conditions, ${ }^{29}$ the hydrogenolysis of $\mathrm{P}-\mathrm{C}$ bonds is a slightly common reaction. It should be furthermore mentioned that, although complex 1 has shown a notable ability to activate $\sigma$-bonds, ${ }^{30}$ including $\mathrm{C}-$ $\mathrm{C},{ }^{31} \mathrm{C}-\mathrm{N},{ }^{32}$ and $\mathrm{C}-\mathrm{O}^{33}$ among others, it had never participated in the rupture of a $\mathrm{C}-\mathrm{P}$ bond.

Complex 2 was isolated as a pale yellow solid in $48 \%$ yield and characterized by $\mathrm{X}$-ray diffraction analysis. Figure 1 gives a view of the structure. The coordination polyhedron around the osmium atom can be rationalized as a pentagonal bipyramid with the phosphine $\mathrm{P}$ atoms at the apical positions $(\mathrm{P}(1)-\mathrm{Os}-$ $\left.\mathrm{P}(2)=169.88(2)^{\circ}\right)$, whereas the hydride ligands and the germylene group define the base of the polyhedron. The OsGe distance, 2.3593(3) A, compares well with those reported for other osmium germylene derivatives. ${ }^{34}$ A DFT-optimized structure confirmed the classical character of the hydride ligands, since it reveals a separation between them of longer than $1.834 \AA$. In toluene, these ligands are involved in thermally activated position exchange processes. Thus, the ${ }^{1} \mathrm{H}$ NMR spectrum at room temperature shows only one high-field resonance for the two groups of inequivalent hydrides, which appears at $-10.45 \mathrm{ppm}$ as a doublet of doublets, with both $\mathrm{H}-$ $\mathrm{P}$ coupling constants of $12.4 \mathrm{~Hz}$. Lowering the temperature of the sample produces a broadening of the resonance. However, decoalescence is not reached even at $183 \mathrm{~K}$. In the same temperature range, the ${ }^{31} \mathrm{P}\left\{{ }^{1} \mathrm{H}\right\}$ NMR spectrum contains two 


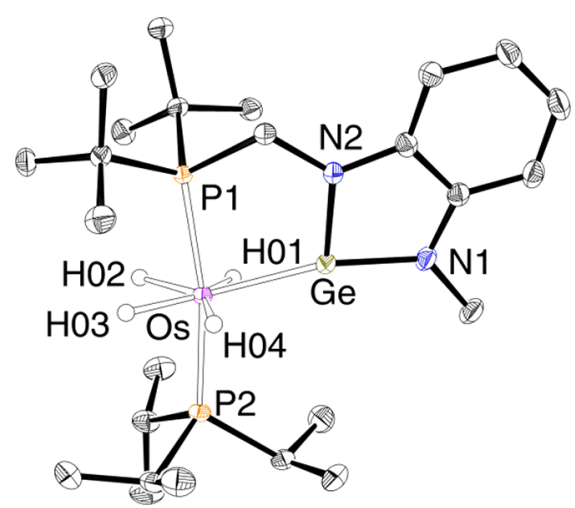

Figure 1. Molecular diagram of complex 2 (50\% probability ellipsoids). Hydrogen atoms (except hydride ligands) are omitted for clarity. Selected bond lengths $(\AA)$ and angles (deg): Os-Ge = 2.3593(3), $\mathrm{P}(1)-\mathrm{Os}-\mathrm{P}(2)=169.88(2), \mathrm{P}(1)-\mathrm{O} s-\mathrm{Ge}=$ 81.038(16), $\mathrm{P}(2)-\mathrm{Os}-\mathrm{Ge}=108.668(17), \mathrm{N}(2)-\mathrm{Ge}-\mathrm{N}(1)=$ 86.49(9), $\mathrm{N}(1)-\mathrm{Ge}-\mathrm{Os}=161.01(7), \mathrm{N}(2)-\mathrm{Ge}-\mathrm{Os}=110.75(6)$.

doublets at 99.8 and $55.5 \mathrm{ppm}$. In agreement with the mutually trans disposition of the phosphorus nuclei, the $\mathrm{P}-\mathrm{P}$ coupling constant is $224.5 \mathrm{~Hz}$.

Complex $\mathbf{2}$ is not exactly the compound initially designed by us but is very similar. The main difference is the lack of a link between the germylene group and the monodentate phosphine. Because complex 2 still fulfills the planned features regarding the Os-Ge interaction, we decided to pursue the initial program.

Reactions of $\mathbf{2}$ with Benzoic and Acetic Acids. The $\mathrm{OsH}_{4}$ moiety is certainly the basic part of 2 , whereas the acid center is located at the germanium atom. In agreement with this, complex 2 reacted with carboxylic acids in toluene at room temperature to give the trihydrides 3 and $\mathbf{4}$ (Scheme 2).

Scheme 2. Reactions of 2 with Benzoic and Acetic Acids

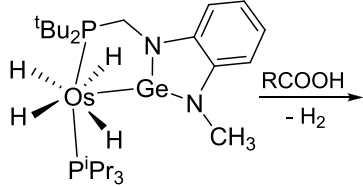

2

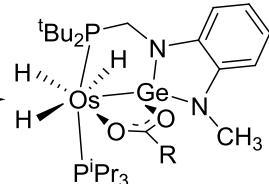

$\mathrm{R}=\mathrm{Ph}(3), \mathrm{CH}_{3}(4)$
These compounds result from the protonation of the basic osmium moiety and the neutralization of the Lewis acidity of the germylene by an arm of the corresponding carboxylate anion. The protonation generates a dihydrogen ligand that is released, occupying the generated coordination vacancy of the other arm of the carboxylate groups.

Complexes 3 and 4 were isolated as pale yellow solids in $56 \%$ and $48 \%$ yields, respectively. Their formation was confirmed by a structural X-ray diffraction analysis of 3 (Figure 2). The addition of the anion to the germanium atom gives rise to a $\mathrm{P}, \mathrm{Ge}, \mathrm{O}$-tridentate ligand, which coordinates in a $\mathrm{fac}$ fashion to the metal center, with bite angles $\mathrm{P}(1)-\mathrm{Os}-\mathrm{Ge}$, $\mathrm{P}(1)-\mathrm{Os}-\mathrm{O}(1)$, and $\mathrm{Ge}-\mathrm{Os}-\mathrm{O}(1)$ of $81.22(4)$, 97.11(13), and $79.87(12)^{\circ}$. The resulting coordination polyhedron around the osmium atom is the typical pentagonal-bipyramidal characteristic of a osmium(IV) polyhydride species with the phosphorus atoms in apical positions $(\mathrm{P}(1)-\mathrm{Os}-\mathrm{P}(2)=$ $\left.170.07(6)^{\circ}\right)$, whereas the hydride ligands and the germanium and oxygen atoms of the tridentate group lie at the base. The

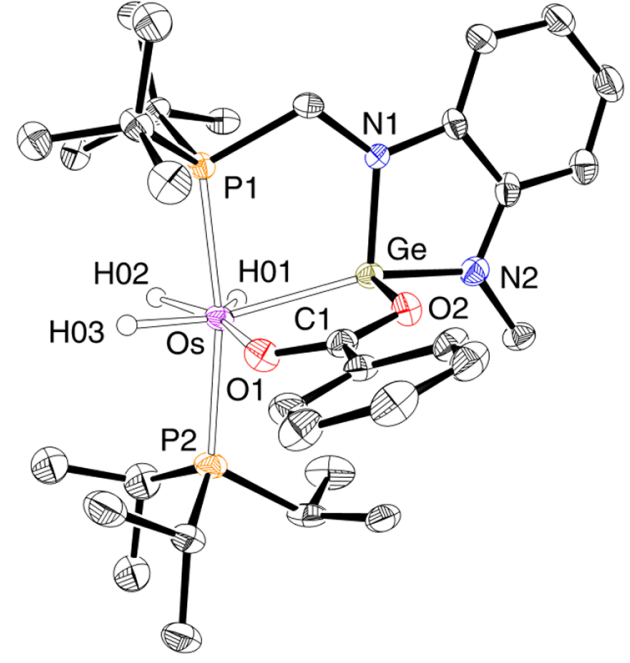

Figure 2. Molecular diagram of complex 3 (50\% probability ellipsoids). Hydrogen atoms (except hydride ligands) are omitted for clarity. Selected bond lengths $(\AA)$ and angles (deg): Os-Ge = 2.4204(7), Os-O(1) = 2.154(5), Ge-O(2) = 2.042(4), O(1)-C(1) $=1.267(8), \mathrm{O}(2)-\mathrm{C}(1)=1.272(8), \mathrm{P}(1)-\mathrm{Os}-\mathrm{P}(2)=170.07(6)$, $\mathrm{P}(1)-\mathrm{Os}-\mathrm{Ge}=81.22(4), \mathrm{P}(2)-\mathrm{Os}-\mathrm{Ge}=108.45(5), \mathrm{P}(1)-\mathrm{Os}-$ $\mathrm{O}(1)=97.11(13), \mathrm{Ge}-\mathrm{Os}-\mathrm{O}(1)=79.87(12), \mathrm{N}(2)-\mathrm{Ge}-\mathrm{N}(1)=$ 86.7(2), $\mathrm{N}(2)-\mathrm{Ge}-\mathrm{O}(2)=100.3(2), \mathrm{N}(1)-\mathrm{Ge}-\mathrm{O}(2)=98.9(2)$, $\mathrm{N}(1)-\mathrm{Ge}-\mathrm{Os}=108.98(15), \mathrm{N}(2)-\mathrm{Ge}-\mathrm{Os}=155.50(17), \mathrm{O}(2)-$ $\mathrm{Ge}-\mathrm{Os}=95.75(12)$.

Os-Ge bond length of 2.4204(7) $\AA$ is about $0.06 \AA$ longer than in 2.The DFT-optimized structure revealed that the $\mathrm{OsH}_{3}$ unit forms a hydride-compressed dihydride system with $\mathrm{H}(01)$ and $\mathrm{H}(02)$ separated by $1.540 \AA$ and $\mathrm{H}(02)$ and $\mathrm{H}(03)$ by $1.752 \AA$. As is usual in this class of polyhydrides, the hydride ligands are involved in thermally activated positional exchange processes in solution. Thus, the ${ }^{1} \mathrm{H}$ NMR spectra of both species, in toluene- $d_{8}$, at room temperature display a broad resonance at about $-11.6 \mathrm{ppm}$ for the inequivalent hydride ligands. In contrast to 2 , this resonance decoalesces between 243 and $233 \mathrm{~K}$, to afford a broad triplet around at $-4 \mathrm{ppm}$ and an $A B$ spin system close to $-15.5 \mathrm{ppm}$. The $\mathrm{H}-\mathrm{H}$ coupling constant values of the latter, $>124 \mathrm{~Hz}$, suggest that the hydrogen nuclei of the compressed dihydride undergo quantum exchange coupling ${ }^{16,32 b, 35}$ in addition to the thermally activated positional exchange process. In agreement with 2, the ${ }^{31} \mathrm{P}\left\{{ }^{1} \mathrm{H}\right\}$ NMR spectra show two doublets at about 84 and 48 ppm with $\mathrm{P}-\mathrm{P}$ coupling constants of around 236 $\mathrm{Hz}$.

Reaction of 2 with Fomic Acid. Once it was known that complex 2 activates the $\mathrm{O}-\mathrm{H}$ bond of usual carboxylic acids, such as benzoic and acetic acids, and established the nature of the resulting compounds, we investigated the behavior of formic acid. The addition of 1.0 equiv of the latter to toluene solutions of the tetrahydride, at room temperature, rapidly produced the release of 1.0 equiv of $\mathrm{H}_{2}$ and the quantitative formation of 5 , the formate counterpart of 3 and 4 . Complex 5 was fully characterized by ${ }^{1} \mathrm{H},{ }^{31} \mathrm{P}\left\{{ }^{1} \mathrm{H}\right\}$, and ${ }^{13} \mathrm{C}\left\{{ }^{1} \mathrm{H}\right\}$ NMR spectroscopy (see the Supporting Information). In agreement with 3 and 4 , the ${ }^{1} \mathrm{H}$ spectrum of 5 contains a broad resonance centered at $-11.73 \mathrm{ppm}$, which is split into a broad signal at $-4.16 \mathrm{ppm}$ and an $\mathrm{AB}$ spin system at $-15.66 \mathrm{ppm}\left({ }^{2} \mathrm{~J}_{\mathrm{H}-\mathrm{H}}>\right.$ $153.0 \mathrm{~Hz}$ ) at temperatures lower than $233 \mathrm{~K}$, whereas the ${ }^{31} \mathrm{P}\left\{{ }^{1} \mathrm{H}\right\}$ spectrum displays two doublets at 84.1 and $48.3 \mathrm{ppm}$ with a $\mathrm{P}-\mathrm{P}$ coupling constant of $234.6 \mathrm{~Hz}$. In solution, 
complex $\mathbf{5}$ is unstable. It releases $\mathrm{CO}_{2}$ to regenerate $\mathbf{2}$ (Scheme 3).

Scheme 3. Stoichiometric Cycle for the Dehydrogenation of Formic Acid to $\mathrm{H}_{2}$ and $\mathrm{CO}_{2}$ Promoted by 2

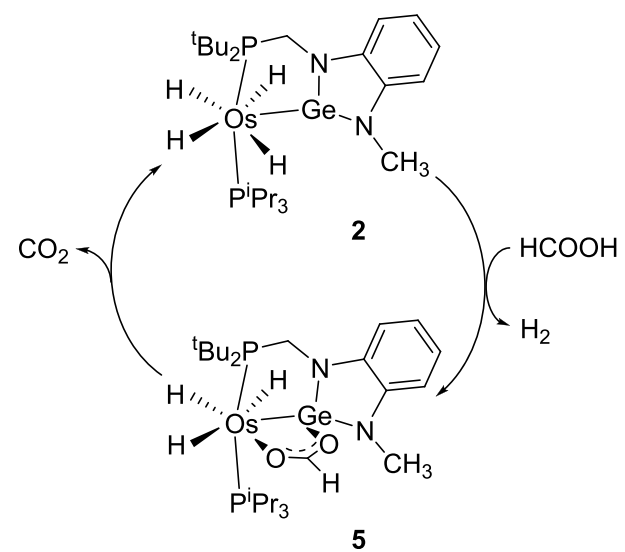

The formation of $\mathbf{5}$ and its decomposition constitutes a cycle for the stoichiometric dehydrogenation of formic acid into $\mathrm{H}_{2}$ and $\mathrm{CO}_{2}$, which is kinetically controlled by the $\mathrm{CO}_{2}$ release, as illustrated Scheme 3. To gain information about the activation parameters of the process, we followed the transformation of 5 into 2 by ${ }^{31} \mathrm{P}\left\{{ }^{1} \mathrm{H}\right\}$ NMR spectroscopy, between 303 and 338 $\mathrm{K}$, as a function of time. Figure 3 shows the spectra of the

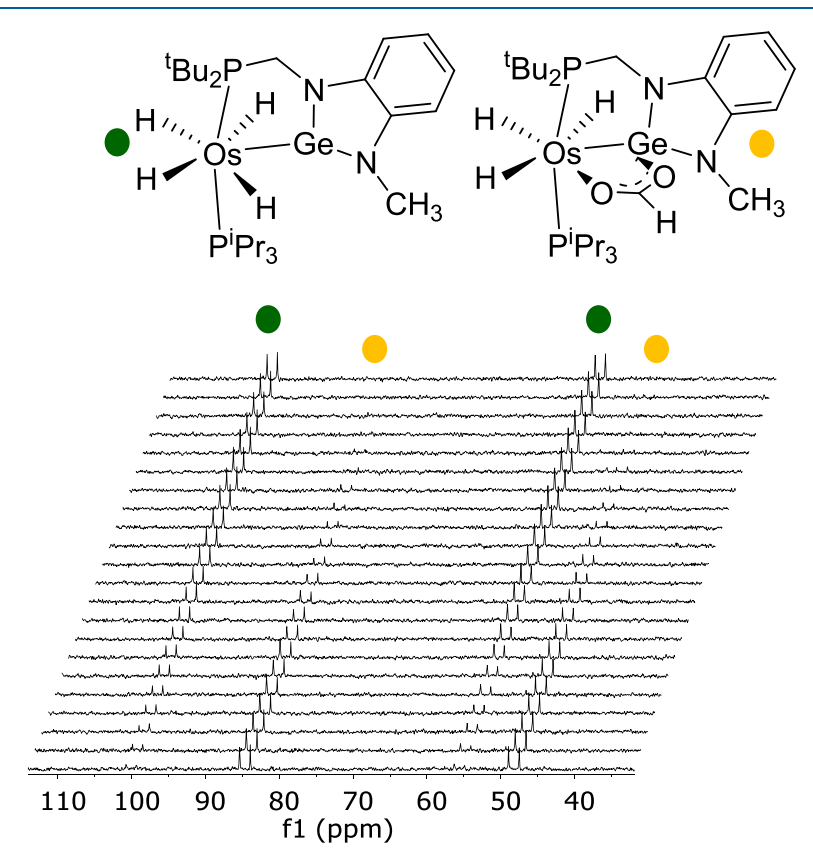

Figure 3. ${ }^{31} \mathrm{P}\left\{{ }^{1} \mathrm{H}\right\}$ spectra $\left(161.98 \mathrm{MHz}\right.$, in toluene- $\left.d_{8}\right)$ for the decarboxylation of 5 at $323 \mathrm{~K}$.

reaction at $323 \mathrm{~K}$. The consumption of $\mathbf{5}$ is an exponential function of time, which fits a first-order process, according to the expression

$$
\ln \left(\frac{[\mathbf{5}]}{[\mathbf{5}]_{0}}\right)=k_{1} t
$$

where $[\mathbf{5}]_{0}$ is the initial concentration of $\mathbf{5}$ and $[\mathbf{5}]$ is the concentration at time $t$. Table 1 gathers the values obtained for
Table 1. Rate Constants for the Transformation of 5 into 2

\begin{tabular}{cc} 
temp $(\mathrm{K})$ & rate constant $k_{\mathrm{st}}\left(\mathrm{min}^{-1}\right)$ \\
303 & 0.001 \\
313 & 0.002 \\
318 & 0.007 \\
328 & 0.017 \\
338 & 0.045 \\
\hline
\end{tabular}

$k_{1}$ in the studied temperature range. The activation parameters calculated through an Eyring analysis (Figure 4) are $\Delta H_{1}^{\ddagger}=21$ $\pm 2 \mathrm{kcal} \mathrm{mol}^{-1}$ and $\Delta S_{1}^{\ddagger}=-3 \pm 5 \mathrm{cal} \mathrm{K}^{-1} \mathrm{~mol}^{-1}$. These values yield an activation energy $\Delta G_{1}^{\ddagger}$ at $298 \mathrm{~K}$ of $22 \pm 3 \mathrm{kcal} \mathrm{mol}^{-1}$.

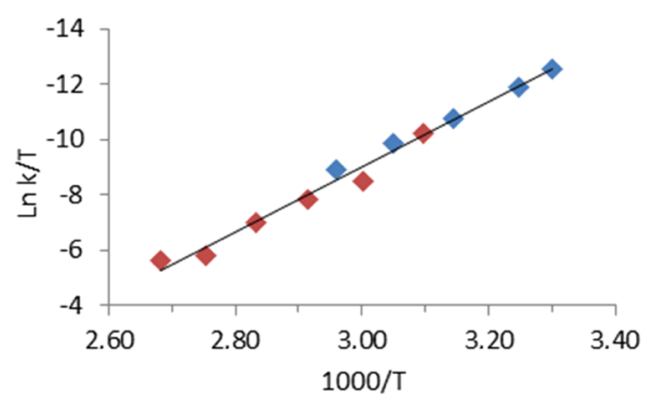

Figure 4. Eyring plot (blue: transformation of 5 into 2; red, catalytic dehydrogenation of formic acid).

Dehydrogenation of Formic Acid Catalyzed by 2: Kinetics and Mechanism. As expected from Scheme 3, complex 2 catalyzes the dehydrogenation of formic acid to $\mathrm{H}_{2}$ and $\mathrm{CO}_{2}$. The catalysis was carried out in toluene, in a closed reactor under constant-volume conditions, between 333 and $373 \mathrm{~K}$. To see whether the cycle of Scheme 3 is furthermore catalytic, the kinetics of the catalysis was also studied under pseudo-first-order conditions. The partial pressure of the generated hydrogen $\left(P_{\mathrm{H}_{2}} ;\right.$ atm $)$ was determined according to eq 2, where $P_{\mathrm{T}}$ and $P_{\mathrm{CO}_{2}}$ are the total pressure and $\mathrm{CO}_{2}$ partial pressure, respectively.

$$
P_{\mathrm{H}_{2}}=P_{T}-P_{\mathrm{CO}_{2}}
$$

Table 2 collects initial rates obtained from the gas evolution experiments by graphing the expression shown in eq 3 , where

Table 2. Kinetic Data for the Dehydrogenation of Formic

\begin{tabular}{|c|c|c|c|c|}
\hline $\begin{array}{c}T \\
(\mathrm{~K})\end{array}$ & $\begin{array}{c}\text { [cat.] } \\
\left(10^{2} \mathrm{M}\right)\end{array}$ & $\begin{array}{c}{[\mathrm{HCOOH}]} \\
(\mathrm{M})\end{array}$ & $\begin{array}{c}\mathrm{d}\left[\mathrm{H}_{2}\right] / \mathrm{d} t \\
\left(10^{2} \mathrm{M} \mathrm{min}^{-1}\right)\end{array}$ & $k\left(\min ^{-1}\right)$ \\
\hline 373 & 0.26 & 0.26 & 0.241 & 0.912 \\
\hline 373 & 0.53 & 0.26 & 0.589 & 1.110 \\
\hline 373 & 0.79 & 0.26 & 0.830 & 1.045 \\
\hline 373 & 1.06 & 0.26 & 0.895 & 0.845 \\
\hline 373 & 1.32 & 0.26 & 1.277 & 0.965 \\
\hline 373 & 0.53 & 0.40 & 0.589 & 1.112 \\
\hline 373 & 0.53 & 0.53 & 0.465 & 0.877 \\
\hline 373 & 0.53 & 0.66 & 0.459 & 0.866 \\
\hline 373 & 0.53 & 0.79 & 0.477 & 0.899 \\
\hline 363 & 0.53 & 0.26 & 0.306 & 0.577 \\
\hline 353 & 0.53 & 0.26 & 0.159 & 0.300 \\
\hline 343 & 0.53 & 0.26 & 0.100 & 0.189 \\
\hline 333 & 0.53 & 0.26 & 0.088 & 0.167 \\
\hline
\end{tabular}
Acid Catalyzed by 2 
$V$ is the volume of the reactor $(\mathrm{L}), R$ is the molar gas constant, $T$ is the temperature $(\mathrm{K})$, and $V_{\text {sol }}$ is the volume of the catalytic solution (L). Figure 5 exemplifies the reactions completed at $373 \mathrm{~K}$, with a concentration of formic acid of $0.26 \mathrm{M}$.

$$
\frac{\mathrm{d}\left[\mathrm{H}_{2}\right]}{\mathrm{d} t}=\left(\frac{\mathrm{d} P_{\mathrm{H}_{2}}}{\mathrm{~d} t}\right) \frac{V}{R T V_{\text {sol }}}
$$

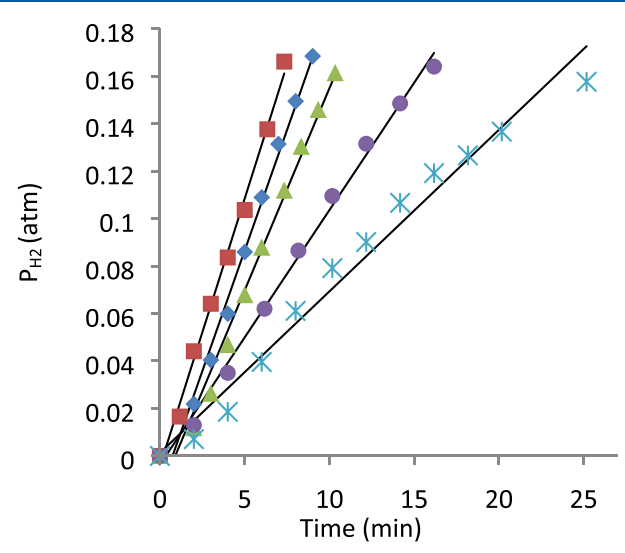

Figure 5. Plot of $P_{\mathrm{H}_{2}}$ vs time $\left(T=373 \mathrm{~K},[\mathrm{HCOOH}]_{0}=0.26 \mathrm{M}\right.$, $10^{2}[2]=0.26 \mathrm{M}$ (pale blue asterisks), $0.53 \mathrm{M}$ (purple circles), $0.79 \mathrm{M}$ (green triangles), $1.06 \mathrm{M}$ (blue diamonds), $1.32 \mathrm{M}$ (red squares)).

A general rate law for the dehydrogenation of formic acid catalyzed by 2 is given by eq 4 :

$$
\frac{\mathrm{d}\left[\mathrm{H}_{2}\right]}{\mathrm{d} t}=k[\mathrm{HCOOH}]_{0}{ }^{a}[\mathbf{2}]^{b}
$$

The rate dependence on the formic acid concentration was studied at $373 \mathrm{~K}$, for a concentration of 2 of $5.3 \times 10^{-3} \mathrm{M}$, with variable initial concentrations of carboxylic acid $\left([\mathrm{HCOOH}]_{0}\right)$ between 0.26 and $0.79 \mathrm{M}$. Under these conditions, the dehydrogenation rate is independent of $[\mathrm{HCOOH}]_{0}$ (Figure 6), indicating that $a=0$ in eq 4 . The

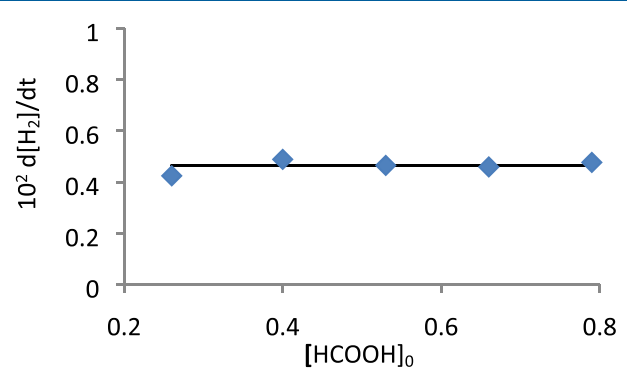

Figure 6. Plot of $\mathrm{d}\left[\mathrm{H}_{2}\right] / \mathrm{d} t$ vs $[\mathrm{HCOOH}]_{0}(T=373 \mathrm{~K},[2]=0.53 \times$ $\left.10^{-2} \mathrm{M}\right)$.

catalyst dependence was also investigated at $373 \mathrm{~K}$, for $[\mathrm{HCOOH}]_{0}=0.26 \mathrm{M}$, increasing the concentration of 2 from $2.6 \times 10^{-3}$ to $1.32 \times 10^{-2} \mathrm{M}$. In contrast to Figure 6, the plot of $\ln \left(\mathrm{d}\left[\mathrm{H}_{2}\right] / \mathrm{d} t\right)$ vs $\ln [2]$ gives a straight line of slope 1.01 (Figure 7 ), in accordance with a first-order dependence: i.e., $b$ $=1$ in eq 4 . Therefore, the rate law for the dehydrogenation of formic acid catalyzed by $\mathbf{2}$ is

$$
\frac{\mathrm{d}\left[\mathrm{H}_{2}\right]}{\mathrm{d} t}=k_{5}[2]
$$

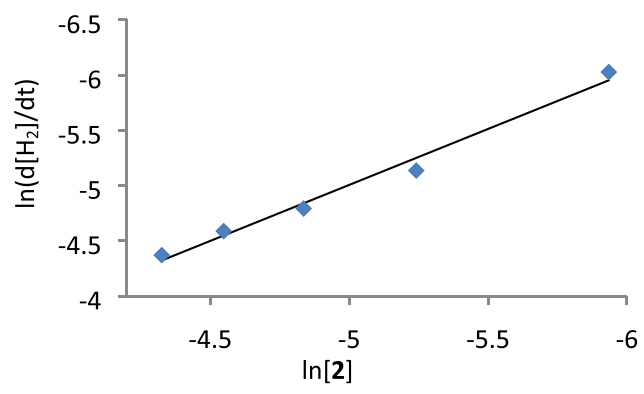

Figure 7. Plot of $\ln \left(\mathrm{d}\left[\mathrm{H}_{2}\right] / \mathrm{d} t\right)$ vs $\ln [2]\left(T=373 \mathrm{~K},[\mathrm{HCOOH}]_{0}=\right.$ $0.26 \mathrm{M})$.

A plot of $\mathrm{d}\left[\mathrm{H}_{2}\right] / \mathrm{d} t$ vs [2] (Figure 8) yields for $k_{5}$ a value of $0.96 \pm 0.10 \mathrm{~min}^{-1}$ at $298 \mathrm{~K}$. The corresponding Eyring analysis

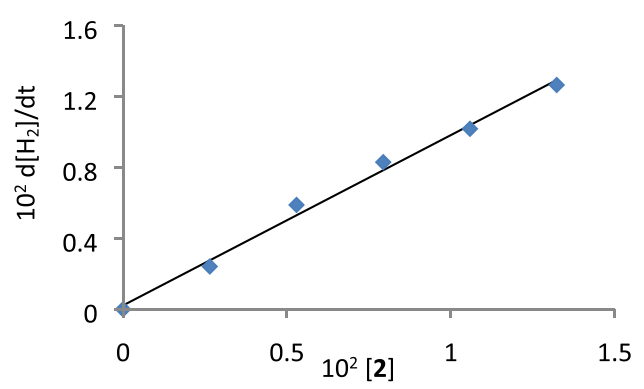

Figure 8. Plot of $\mathrm{d}\left[\mathrm{H}_{2}\right] / \mathrm{d} t$ vs $[2]\left(T=373 \mathrm{~K},[\mathrm{HCOOH}]_{0}=0.26\right.$ M).

(Figure 4, red points) affords values of $\Delta H_{5}^{\ddagger}=19 \pm 1 \mathrm{kcal}$ $\mathrm{mol}^{-1}, \Delta S_{5}^{\ddagger}=-7 \pm 3 \mathrm{cal} \mathrm{K}^{-1} \mathrm{~mol}^{-1}$, and $\Delta G_{5}^{\ddagger}=21 \pm 2 \mathrm{kcal}$ $\mathrm{mol}^{-1}$ at $298 \mathrm{~K}$. To our delight, they compare well with those obtained for the stoichiometric release of $\mathrm{CO}_{2}$ from 5 . As it should be, since both Eyring analyses fit the same straight line, which leads to common activation parameters for the catalysis and the stoichiometric release of $\mathrm{CO}_{2}$ from 5 of $\Delta H^{\ddagger}=23 \pm 1$ $\mathrm{kcal} \mathrm{mol}{ }^{-1}, \Delta S^{\ddagger}=4 \pm 3 \mathrm{cal} \mathrm{K}^{-1} \mathrm{~mol}^{-1}$, and $\Delta G^{\ddagger}=21 \pm 2 \mathrm{kcal}$ $\mathrm{mol}^{-1}$ at $298 \mathrm{~K}$. Figure 4 gives overwhelming evidence supporting the catalytic nature of the cycle shown in Scheme 3, which was furthermore reinforced by the ${ }^{31} \mathrm{P}\left\{{ }^{1} \mathrm{H}\right\}$ NMR spectra of catalytic solutions quenched at half of the dehydrogenation. They reveal that complex $\mathbf{5}$ is the only osmium species present in a detectable concentration while formic acid is not completely consumed. The value of $\Delta G^{\ddagger}$ at $298 \mathrm{~K}$ lies in the central part of the range previously reported for this parameter in the dehydrogenation of formic acid catalyzed by other homogeneous systems (17-26 kcal $\left.\mathrm{mol}^{-1}\right) \cdot{ }^{18 \mathrm{~b}, 26 \mathrm{c}, 36}$

The dehydrogenation of formic acid catalyzed by 2 shows significant differences with regard to those promoted by traditional bifunctional catalysts, from a mechanistic point of view. In contrast to the traditional systems, the hydrogen formation (the fast stage) exclusively occurs on the coordination sphere of the basic metal center, whereas the $\mathrm{CO}_{2}$ release (the catalytic rate-determining step) is a cooperative process between the metal and the $\sigma$-donor Lewis acid. To gain information about the intimate details of the cooperation, we carried out DFT calculations (wB97XD/ $\mathrm{SDD} / \mathrm{cc}-\mathrm{pVDZ}$ ) with regard to the $\mathrm{CO}_{2}$ formation. The $\Delta G$ values were calculated in toluene at $298.15 \mathrm{~K}$ and $1 \mathrm{~atm}$. Figure 9 shows the calculated profiles, whereas Scheme 4 collects the optimized intermediates. 


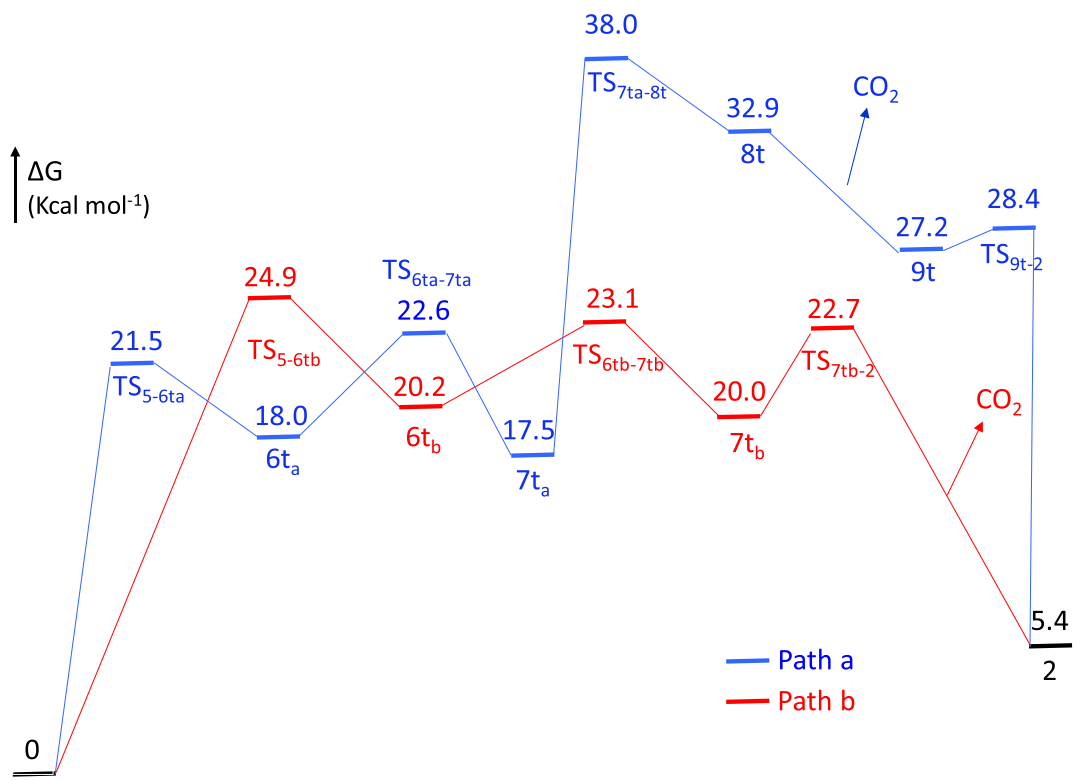

Figure 9. Energy profiles for the transformation of 5 into 2 .

Scheme 4. DFT-Calculated Intermediates for Paths a (Blue) and b (Red)

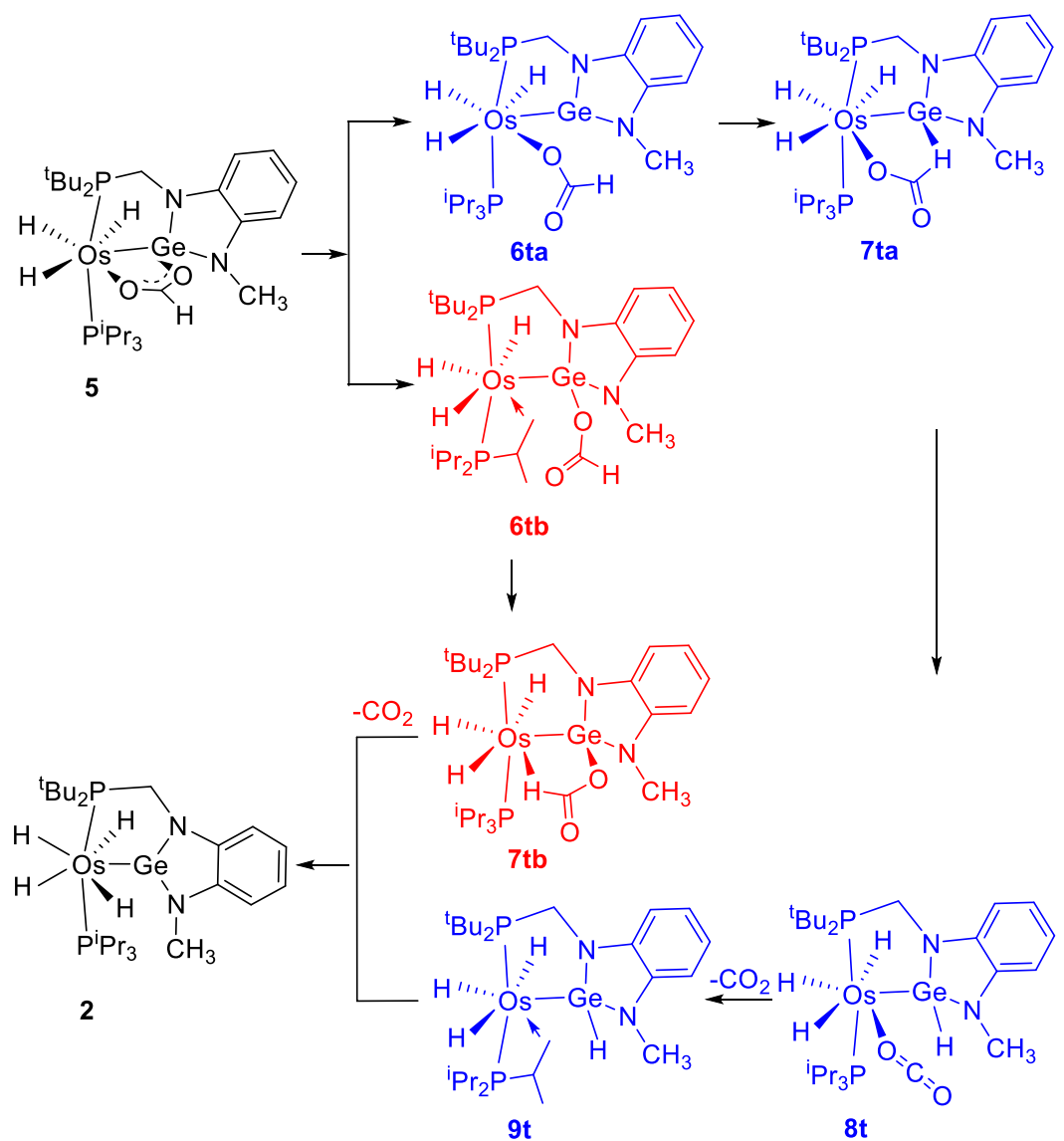

The stoichiometric decomposition of $\mathbf{5}$ into 2 and $\mathrm{CO}_{2}$ is endergonic by $5.4 \mathrm{kcal} \mathrm{mol}^{-1}$, where the gas elimination acts as a driving force of the reaction. Under catalytic conditions, the absorbed energy is compensated by the exothermic hydrogen formation. The process can be started in two alternative ways (paths $\mathrm{a}$ and $\mathrm{b}$ ), which involve the rupture of the $\mathrm{Ge}-\mathrm{O}$ bond to form intermediate $\mathbf{6 t}_{\mathbf{a}}$ (path a) or the rupture of the Os-O bond to give intermediate $\mathbf{6 t}_{\mathrm{b}}$ (path $\mathrm{b}$ ). According to path $\mathrm{a}$, once intermediate $\mathbf{6} \mathbf{t}_{\mathrm{a}}$ is formed, the monodentate formate ligand pivots around the Os-O bond to situate its hydrogen on the Ge atom. In this context, it should be noted that a $\beta$ hydrogen elimination of the formate hydrogen atom is not possible, due to the saturated character of the metal center. The resulting species $7 t_{a}$ evolves to $8 t$ by means of the rupture of the formate $\mathrm{C}-\mathrm{H}$ bond. The subsequent release from the coordinated $\mathrm{CO}_{2}$ molecule leads to the germyl intermediate $9 \mathbf{t}$, 
which undergoes $\alpha$-hydrogen elimination to regenerate 2 . This route must overcome an activation energy of $38.0 \mathrm{kcal} \mathrm{mol}^{-1}$, which is out of the range from the $\Delta G^{\ddagger}$ values experimentally obtained. Thus, path a must be rejected as a reasonable proposal. The unsaturated intermediate $\mathbf{6 t}_{\mathbf{b}}$, formed according to path $b$, saturates the metal coordination sphere by means of an agostic interaction with a methyl $\mathrm{C}-\mathrm{H}$ bond of the triisopropylphosphine. Its formation takes place with an activation energy of $24.9 \mathrm{kcal} \mathrm{mol}^{-1}$. This value is the highest of the profile associated with path $b$ and compares well with the experimental value of $\Delta G^{\ddagger}$, supporting path $\mathrm{b}$ as the only one possible. The formate group, which is now $\kappa^{1}$-coordinated to the Ge atom, pivots around the latter to approach its hydrogen atom to the osmium center. As a result, the formate hydrogen atom displaces the methyl $\mathrm{C}-\mathrm{H}$ bond from the osmium to afford $7 \mathbf{t}_{\mathfrak{b}}$, which finally loses $\mathrm{CO}_{2}$ to yield 2 . The NBO charges at $\mathbf{T S}_{7 \mathrm{tb}-2}$ strongly support the basic character of the metal center and the acidic nature of the $\mathrm{Ge}$ atom (Chart 2).

Chart 2. NBO Charges at $\mathrm{TS}_{7 \mathrm{tb}-2}$

$\mathbf{T S}_{7 \mathrm{tb}-2}$

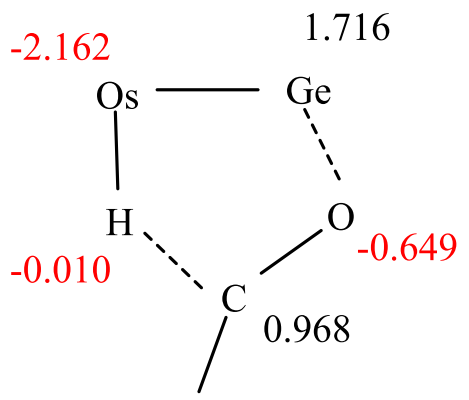

$\mathrm{O}$

$-0.594$

$\mathrm{CO}_{2}$ formation usually occurs by $\beta$-hydrogen elimination on unsaturated $\mathrm{M}\left\{\kappa^{1}-\mathrm{OC}(\mathrm{O}) \mathrm{H}\right\}$ intermediates ${ }^{37}$ or hydrogen abstraction on saturated species of the same type. In the second case, the metal center of the catalyst slips from the coordinated oxygen into the hydrogen atom before releasing the $\mathrm{CO}_{2}$ molecule. ${ }^{18 a, 36 b, 38}$ The movement described herein is an alternative manner of implementing the $\mathrm{CO}_{2}$ release.

\section{CONCLUDING REMARKS}

An alternative class of bifunctional catalysts can be assembled by coordination of $\sigma$-donor Lewis acids to platinum-groupmetal basic fragments. In contrast to what happens with the previously reported bifunctional catalysts, this design allows enhancing the basicity of the base and the acidity of the acid. As a proof of this, we have prepared a bifunctional catalyst, for the dehydrogenation of formic acid to $\mathrm{H}_{2}$ and $\mathrm{CO}_{2}$, coordinating a bidentate phosphine-tetrylene ligand to an osmium(IV) tetrahydride metal fragment. Furthermore, we have discovered during the preparation of this complex that polyhydrides with a high number of hydride ligands, such as the osmium hexahydride $\mathrm{OsH}_{6}\left(\mathrm{P}^{\mathrm{i}} \mathrm{Pr}_{3}\right)_{2}$, are able to perform the hydrogenolysis of $\mathrm{P}-\mathrm{C}\left(\mathrm{sp}^{3}\right)$ bonds.

The kinetics of the formic acid dehydrogenation, the characterization of the resting state of the catalysis along with the establishment of the activation parameters of its evolution, and DFT calculations regarding the rate-determining step prove that the prepared $\mathrm{Os}(\mathrm{IV})-\mathrm{Ge}(\mathrm{II})$ catalyst works in a manner different from that of the traditional bifunctional catalysts, based on an acid metal fragment and a cooperative basic ligand. In contrast to the traditional systems, the hydrogen formation (the fast stage) exclusively occurs on the coordination sphere of the basic metal center, whereas the $\mathrm{CO}_{2}$ release (the rate-determining step) is a cooperative processes involving the metal and the $\sigma$-donor Lewis acid. The process taking place during the cooperation is also an alternative manner of implementing the $\mathrm{CO}_{2}$ release.

\section{EXPERIMENTAL SECTION}

General Information. General experimental details, X-ray analysis, spectroscopic and general instrumental techniques, and computational information are given in the Supporting Information. Chemical shifts are expressed in ppm, whereas the coupling constants $J$ and $N\left(N=J_{\mathrm{H}-\mathrm{P}}+J_{\mathrm{H}-\mathrm{P}^{\prime}}\right.$ for ${ }^{1} \mathrm{H}$ and $N=J_{\mathrm{C}-\mathrm{P}}+J_{\mathrm{C}-\mathrm{P}^{\prime}}$ for $\left.{ }^{13} \mathrm{C}\left\{{ }^{1} \mathrm{H}\right)\right)$ are given in $\mathrm{Hz}$. The complex $\mathrm{OsH}_{6}\left(\mathrm{P}^{i} \mathrm{Pr}_{3}\right)_{2}{ }^{39}$ and 1,3-bis(di-tertbutylphosphanylmethyl)-1,3-dihydro-2 $\lambda^{2}$-benzo $[d][1,3,2]$ diazagermole ${ }^{27 a}$ were prepared as previously described.

Preparation of 2. The complex $\mathrm{OsH}_{6}\left(\mathrm{P}^{i} \mathrm{Pr}_{3}\right)_{2}$ (332 mg, 0.643 $\mathrm{mmol})$ and 1,3-bis((di-tert-butylphosphanyl)methyl)-1,3-dihydro- $2 \lambda^{2}$ benzo $[d][1,3,2]$ diazagermole $(350 \mathrm{mg}, 0.707 \mathrm{mmol})$ were dissolved in $10 \mathrm{~mL}$ of toluene, in a Schlenk with a Teflon stopcock, and heated at $110{ }^{\circ} \mathrm{C}$ for $18 \mathrm{~h}$. The orange solution was transferred to a Schlenk and evaporated to dryness. The crude product was washed with pentane $(3 \times 2 \mathrm{~mL})$, at $-78{ }^{\circ} \mathrm{C}$, to afford a pale yellow solid: yield $213 \mathrm{mg}$ (48\%). Crystals suitable for X-ray diffraction analysis were obtained from a concentrated solution of the solid in pentane at -30 ${ }^{\circ} \mathrm{C}$ in the glovebox. Anal. Calcd for $\mathrm{C}_{25} \mathrm{H}_{52} \mathrm{GeN}_{2} \mathrm{OsP}_{2}$ : C, 42.56; $\mathrm{H}$, 7.43; N, 3.97. Found: $\mathrm{C}, 42.84 ; \mathrm{H}, 7.47 ; \mathrm{N}, 4.22$. HRMS (electrospray, $m / z$ ): calcd for $\mathrm{C}_{25} \mathrm{H}_{49} \mathrm{GeN}_{2} \mathrm{OsP}_{2}[\mathrm{M}-3 \mathrm{H}]^{+}$, 705.2192; found, 705.2213. IR $\left(\mathrm{cm}^{-1}\right): \nu(\mathrm{OsH}) 2064(\mathrm{w}) .{ }^{1} \mathrm{H}$ NMR $\left(300 \mathrm{MHz}\right.$, benzene- $\left.d_{6}, 298 \mathrm{~K}\right): \delta 7.18-7.02(\mathrm{~m}, 2 \mathrm{H}, \mathrm{Ph}), 6.98$ $\left(\mathrm{d},{ }^{3} \mathrm{~J}_{\mathrm{H}-\mathrm{H}}=7.6,1 \mathrm{H}, \mathrm{Ph}\right), 6.76\left(\mathrm{~d},{ }^{3} \mathrm{~J}_{\mathrm{H}-\mathrm{H}}=7.6,1 \mathrm{H}, \mathrm{Ph}\right), 3.24(\mathrm{~s}, 3 \mathrm{H}$, $\left.\mathrm{NCH}_{3}\right), 2.96\left(\mathrm{~d},{ }^{2} J_{\mathrm{H}-\mathrm{P}}=4.1,2 \mathrm{H}, \mathrm{NCH}_{2}\right), 1.72\left(\mathrm{sept},{ }^{3} J_{\mathrm{H}-\mathrm{H}}=6.9,3 \mathrm{H}\right.$, $\left.\mathrm{CH}\left(\mathrm{CH}_{3}\right)_{2}\right), 1.25\left(\mathrm{~d},{ }^{3} J_{\mathrm{H}-\mathrm{P}}=12.3,18 \mathrm{H},{ }^{t} \mathrm{Bu}\right), 1.18\left(\mathrm{dd},{ }^{3} J_{\mathrm{H}-\mathrm{P}}=13.1\right.$, $\left.{ }^{3} J_{\mathrm{H}-\mathrm{H}}=6.9,18 \mathrm{H}, \mathrm{PCH}\left(\mathrm{CH}_{3}\right)_{2}\right),-10.45\left(\mathrm{dd},{ }^{2} J_{\mathrm{H}-\mathrm{P}}={ }^{2} J_{\mathrm{H}^{\prime}-\mathrm{P}^{\prime}}=12.4\right.$, $\left.4 \mathrm{H}, \mathrm{OsH}_{4}\right) .{ }^{1} \mathrm{H}$ NMR $\left(400 \mathrm{MHz}\right.$, toluene- $d_{8}, 193 \mathrm{~K}$, high-field region): $\delta-10.40\left(\mathrm{br} \mathrm{dd},{ }^{2} J_{\mathrm{H}-\mathrm{P}}={ }^{2} J_{\mathrm{H}^{\prime}-\mathrm{P}^{\prime}}=12.8 \mathrm{~Hz}, 4 \mathrm{H}, \mathrm{OsH}_{4}\right)$. $T_{1}(\mathrm{~min})\left(\mathrm{ms}, 400 \mathrm{MHz}\right.$, toluene- $\left.d_{8}, 223 \mathrm{~K}\right): 220 \pm 22(-10.45 \mathrm{ppm})$. ${ }^{31} \mathrm{P}\left\{{ }^{1} \mathrm{H}\right\}$ NMR $\left(121 \mathrm{MHz}\right.$, benzene- $\left.d_{6}, 298 \mathrm{~K}\right): \delta 99.8\left(\mathrm{~d},{ }^{2} J_{\mathrm{P}-\mathrm{P}}=\right.$ 224.5), $55.5\left(\mathrm{~d},{ }^{2} J_{\mathrm{P}-\mathrm{P}}=224.5\right) .{ }^{13} \mathrm{C}\left\{{ }^{1} \mathrm{H}\right\}$-APT NMR plus HSQC and HMBC $\left(75 \mathrm{MHz}\right.$, benzene- $\left.d_{6}, 298 \mathrm{~K}\right): \delta 144.2\left(\mathrm{~s}, \mathrm{C}_{\mathrm{q}}-\mathrm{Ph}\right), 140.3(\mathrm{~d}$, $\left.{ }^{3} J_{\mathrm{C}-\mathrm{P}}=12.1, \mathrm{C}_{\mathrm{q}}-\mathrm{Ph}\right), 119.0(\mathrm{~s}, \mathrm{Ph}), 117.5(\mathrm{~s}, \mathrm{Ph}), 110.0(\mathrm{~s}, \mathrm{Ph})$, 108.3.0 (s, Ph), 35.1 (dd, $\left.{ }^{1} J_{\mathrm{C}-\mathrm{P}}=19.3,{ }^{3} J_{\mathrm{C}-\mathrm{P}}=1.7, \mathrm{C}_{\mathrm{q}}{ }^{\mathrm{t}} \mathrm{Bu}\right), 32.5(\mathrm{~s}$, $\left.\mathrm{NCH}_{3}\right), 31.8\left(\mathrm{~d},{ }^{1} J_{\mathrm{C}-\mathrm{P}}=25.5, \mathrm{NCH}_{2} \mathrm{P}\right), 30.2\left(\mathrm{~d},{ }^{2} J_{\mathrm{C}-\mathrm{P}}=4.0\right.$, $\left.\mathrm{CH}_{3}{ }^{-} \mathrm{Bu}\right), 29.4\left(\mathrm{dd},{ }^{1} J_{\mathrm{C}-\mathrm{P}}=24.5,{ }^{3} J_{\mathrm{C}-\mathrm{P}}=2.1, \mathrm{CH}\left(\mathrm{CH}_{3}\right)_{2}\right), 21.06(\mathrm{~s}$, $\left.\mathrm{CH}\left(\mathrm{CH}_{3}\right)_{2}\right)$.

Reaction of 2 with Benzoic Acid. Compound 2 (100 mg, 0.142 $\mathrm{mmol})$ and benzoic acid $(19.0 \mathrm{mg}, 0.156 \mathrm{mmol})$ in $5 \mathrm{~mL}$ of toluene were stirred for $16 \mathrm{~h}$ at room temperature. After evaporation to dryness, $3 \mathrm{~mL}$ of pentane was added to form a pale yellow solid of complex 3, which was washed with pentane $(3 \times 2 \mathrm{~mL})$ : yield $66 \mathrm{mg}$ $(56 \%)$. Crystals suitable for an X-ray diffraction analysis were obtained from a concentrated solution of the solid in pentane at $-30{ }^{\circ} \mathrm{C}$ in the glovebox. Anal. Calcd for $\mathrm{C}_{32} \mathrm{H}_{56} \mathrm{GeN}_{2} \mathrm{O}_{2} \mathrm{OsP}_{2}$ : $\mathrm{C}$, 46.55; H, 6.84; N, 3.39. Found: C, 46.31; H, 6.56; N, 3.78. HRMS (electrospray, $m / z$ ): calcd for $\mathrm{C}_{32} \mathrm{H}_{54} \mathrm{GeN}_{2} \mathrm{O}_{2} \mathrm{OsP}_{2}[\mathrm{M}-2 \mathrm{H}]^{+}$, 826.2482; found, 826.2478. IR $\left(\mathrm{cm}^{-1}\right): \nu(\mathrm{OsH}) 1995(\mathrm{~m}) ; \nu(\mathrm{C}-\mathrm{O})$ 1530 (s); 1488 (s). ${ }^{1} \mathrm{H}$ NMR (300 MHz, toluene- $\left.d_{8}, 298 \mathrm{~K}\right): \delta 7.92$ $\left(\mathrm{dd},{ }^{3} J_{\mathrm{H}-\mathrm{H}}=8.0,{ }^{4} J_{\mathrm{H}-\mathrm{H}}=1.8,2 \mathrm{H}, \mathrm{PhCOO}\right), 7.16(\mathrm{~m}, 1 \mathrm{H}, \mathrm{Ph}), 7.10$ $(\mathrm{m}, 1 \mathrm{H}, \mathrm{Ph}), 7.03(\mathrm{~m}, 3 \mathrm{H}, \mathrm{Ph}), 6.85(\mathrm{~m}, 2 \mathrm{H}, \mathrm{Ph}), 3.53(\mathrm{~s}, 3 \mathrm{H}$ $\left.\mathrm{NCH}_{3}\right), 3.24\left(\mathrm{dd},{ }^{2} J_{\mathrm{H}-\mathrm{P}}=12.6,{ }^{2} J_{\mathrm{H}-\mathrm{H}}=1.8,1 \mathrm{H}, \mathrm{NCH}_{2}\right), 2.53(\mathrm{dd}$, $\left.{ }^{2} \mathrm{~J}_{\mathrm{H}-\mathrm{P}}=12.4,{ }^{2} \mathrm{~J}_{\mathrm{H}-\mathrm{H}}=1.8,1 \mathrm{H}, \mathrm{NCH}_{2}\right), 1.78\left(\mathrm{~m}, 3 \mathrm{H}, \mathrm{PCH}\left(\mathrm{CH}_{3}\right)_{2}\right)$, $1.22\left(\mathrm{dd},{ }^{2} J_{\mathrm{H}-\mathrm{P}}=13.0,{ }^{3} J_{\mathrm{H}-\mathrm{H}}=7.1,9 \mathrm{H}, \mathrm{PCH}\left(\mathrm{CH}_{3}\right)_{2}\right), 1.06\left(\mathrm{dd},{ }^{2} J_{\mathrm{H}-\mathrm{P}}\right.$ $\left.=13.0,{ }^{3} \mathrm{~J}_{\mathrm{H}-\mathrm{H}}=7.1,9 \mathrm{H}, \mathrm{PCH}\left(\mathrm{CH}_{3}\right)_{2}\right), 1.12\left(\mathrm{~d},{ }^{3} \mathrm{~J}_{\mathrm{H}-\mathrm{P}}=12.8,9 \mathrm{H}\right.$, 
$\left.\mathrm{P}^{t} \mathrm{Bu}_{2}\right), 1.01\left(\mathrm{~d},{ }^{3} J_{\mathrm{H}-\mathrm{P}}=11.9,9 \mathrm{H}, \mathrm{P}^{t} \mathrm{Bu}_{2}\right),-11.55\left(\mathrm{br}, 3 \mathrm{H}, \mathrm{OsH}_{3}\right) .{ }^{1} \mathrm{H}$ NMR (300 MHz, toluene- $d_{8}, 183 \mathrm{~K}$, high-field region): $\delta-3.64$ (br s, $1 \mathrm{H}, \mathrm{OsH}),-15.12\left(\mathrm{AB}\right.$ system, $\Delta \nu=1080 \mathrm{~Hz}, J_{\mathrm{A}-\mathrm{B}}=162 \mathrm{~Hz}, 2 \mathrm{H}$, $\left.\mathrm{OsH}_{2}\right) . T_{1}(\mathrm{~min})\left(\mathrm{ms}, \mathrm{Os}-\mathrm{H}, 300 \mathrm{MHz}\right.$, toluene- $\left.d_{8}, 223 \mathrm{~K}\right): 64 \pm 6$ $(-16.69 \mathrm{ppm})$; the $T_{1}(\mathrm{~min})$ value of the resonance at $-4.08 \mathrm{ppm}$ could not be calculated due to its broadness. ${ }^{31} \mathrm{P}\left\{{ }^{1} \mathrm{H}\right\}$ NMR (121 $\mathrm{MHz}$, toluene- $\left.d_{8}, 298 \mathrm{~K}\right): \delta 84.6\left(\mathrm{~d},{ }^{2} J_{\mathrm{P}-\mathrm{P}}=236.5\right), 49.2\left(\mathrm{~d},{ }^{2} J_{\mathrm{P}-\mathrm{P}}=\right.$ 236.5). ${ }^{13} \mathrm{C}\left\{{ }^{1} \mathrm{H}\right\}$-APT NMR plus HSQC and HMBC $(75 \mathrm{MHz}$, toluene- $\left.d_{8}, 298 \mathrm{~K}\right): \delta 176.2\left(\mathrm{~s}, \mathrm{C}_{\mathrm{q}}-\mathrm{COO}\right), 145.3\left(\mathrm{~s}, \mathrm{C}_{\mathrm{q}}-\mathrm{Ph}\right), 140.6(\mathrm{~d}$, $\left.{ }^{3} J_{\mathrm{C}-\mathrm{P}}=12.8, \mathrm{C}_{\mathrm{q}}-\mathrm{Ph}\right), 140.5\left(\mathrm{~s}, \mathrm{C}_{\mathrm{q}}-\mathrm{Ph}\right), 132.1(\mathrm{~s}, \mathrm{Ph}), 130.5(\mathrm{~s}, \mathrm{Ph})$, $128.3(\mathrm{~s}, \mathrm{Ph}), 117.5(\mathrm{~s}, \mathrm{Ph}), 116.5(\mathrm{~s}, \mathrm{Ph}), 108.5(\mathrm{~s}, \mathrm{Ph}), 107.4(\mathrm{~s}$, $\mathrm{Ph}), 37.1\left(\mathrm{~d},{ }^{1} J_{\mathrm{C}-\mathrm{P}}=22.4, \mathrm{C}_{\mathrm{q}}-\mathrm{P}^{t} \mathrm{Bu}_{2}\right), 36.1\left(\mathrm{dd},{ }^{1} J_{\mathrm{C}-\mathrm{P}}=18.2,{ }^{3} J_{\mathrm{C}-\mathrm{P}}=\right.$ 2.7, $\left.\mathrm{C}_{\mathrm{q}}-\mathrm{P}^{t} \mathrm{Bu}_{2}\right), 32.8\left(\mathrm{~s}, \mathrm{NCH}_{3}\right), 31.2\left(\mathrm{~d},{ }^{1} J_{\mathrm{C}-\mathrm{P}}=26.4, \mathrm{NCH}_{2}\right), 29.4$ $\left(\mathrm{dd},{ }^{2} J_{\mathrm{C}-\mathrm{P}}=19.3,{ }^{4} J_{\mathrm{C}-\mathrm{P}}=3.3, \mathrm{CH}_{3}{ }^{-} \mathrm{Bu}\right), 26.7\left(\mathrm{dd},{ }^{1} J_{\mathrm{C}-\mathrm{P}}=23.6,{ }^{3} J_{\mathrm{C}-\mathrm{P}}\right.$ $\left.=1.9, \mathrm{CH}\left(\mathrm{CH}_{3}\right)_{2}\right), 20.5\left(\mathrm{~s}, \mathrm{CH}\left(\mathrm{CH}_{3}\right)_{2}\right), 20.0\left(\mathrm{~s}, \mathrm{CH}\left(\mathrm{CH}_{3}\right)_{2}\right)$.

Reaction of $\mathbf{2}$ with Acetic Acid. A solution of complex 2 (100 $\mathrm{mg}, 0.142 \mathrm{mmol}$ ) in $5 \mathrm{~mL}$ of toluene was treated with glacial acetic acid $(9.4 \mathrm{mg}, 0.156 \mathrm{mmol}, 9 \mu \mathrm{L})$. The mixture was stirred for $4 \mathrm{~h}$ at room temperature. After evaporation of the solvent, the residue was extracted with pentane $(3 \times 1 \mathrm{~mL})$. The liquors were evaporated to dryness to afford a pale yellow solid of complex 4: yield $52 \mathrm{mg}(48 \%)$ Anal. Calcd for $\mathrm{C}_{27} \mathrm{H}_{54} \mathrm{GeN}_{2} \mathrm{O}_{2} \mathrm{OsP}_{2}$ : C, 42.47; H, 7.13; N, 3.67. Found: C, 42.73; H, 7.39; N, 4.04. HRMS (electrospray, $m / z$ ): calcd for $\mathrm{C}_{27} \mathrm{H}_{52} \mathrm{GeN}_{2} \mathrm{O}_{2} \mathrm{OsP}_{2}[\mathrm{M}-2 \mathrm{H}]^{+}$, 764.2325; found, 764.2314. IR $\left(\mathrm{cm}^{-1}\right): \nu(\mathrm{OsH}) 2001(\mathrm{~m}) ; \nu(\mathrm{C}-\mathrm{O}) 1546(\mathrm{~s}), 1488(\mathrm{~s}) .{ }^{1} \mathrm{H}$ NMR $\left(300 \mathrm{MHz}\right.$, benzene- $\left.d_{6}, 298 \mathrm{~K}\right): \delta 7.09(\mathrm{~m}, 2 \mathrm{H}, \mathrm{Ph}), 6.89(\mathrm{~m}, 2 \mathrm{H}$, $\mathrm{Ph}), 3.44\left(\mathrm{~s}, 3 \mathrm{H}, \mathrm{NCH}_{3}\right), 3.26\left(\mathrm{dd},{ }^{2} J_{\mathrm{H}-\mathrm{P}}=12.7,{ }^{2} J_{\mathrm{H}-\mathrm{H}}=1.5,1 \mathrm{H}\right.$, $\left.\mathrm{NCH}_{2}\right), 2.62\left(\mathrm{dd},{ }^{2} J_{\mathrm{H}-\mathrm{P}}=12.3,{ }^{2} J_{\mathrm{H}-\mathrm{H}}=1.5,1 \mathrm{H}, \mathrm{NCH}_{2}\right), 1.81(\mathrm{~m}$, $\left.6 \mathrm{H}, \mathrm{CH}_{3} \mathrm{COO}+\mathrm{PCH}\left(\mathrm{CH}_{3}\right)_{2}\right), 1.25-0.95\left(\mathrm{~m}, 36 \mathrm{H}, \mathrm{PCH}\left(\mathrm{CH}_{3}\right)_{2}+\right.$ $\left.\mathrm{P}^{t} \mathrm{Bu}_{2}\right),-11.65\left(\mathrm{br}, 3 \mathrm{H}, \mathrm{OsH}_{3}\right) .{ }^{1} \mathrm{H}$ NMR $\left(300 \mathrm{MHz}\right.$, toluene- $d_{8}, 183$ $\mathrm{K}$, high-field region): $\delta-3.83$ (br s, $1 \mathrm{H}, \mathrm{OsH}),-15.37$ (AB system, $\left.\Delta \nu=1083 \mathrm{~Hz}, J_{\mathrm{A}-\mathrm{B}}=124.5 \mathrm{~Hz}, 2 \mathrm{H}, \mathrm{OsH}_{2}\right) . T_{1}(\min )(\mathrm{ms}, \mathrm{Os}-\mathrm{H}$, $300 \mathrm{MHz}$, toluene- $\left.d_{8}, 218 \mathrm{~K}\right): 41 \pm 4(-17.17 \mathrm{ppm})$; the $T_{1}(\mathrm{~min})$ value of the resonance at $-4.04 \mathrm{ppm}$ could not be calculated due to the broadness of it. ${ }^{31} \mathrm{P}\left\{{ }^{1} \mathrm{H}\right\}$ NMR $\left(121 \mathrm{MHz}\right.$, benzene- $\left.d_{6}, 298 \mathrm{~K}\right): \delta$ $84.96\left(\mathrm{~d},{ }^{2} J_{\mathrm{P}-\mathrm{P}}=237.5\right), 48.32\left(\mathrm{~d},{ }^{2} J_{\mathrm{P}-\mathrm{P}}=237.5\right) .{ }^{13} \mathrm{C}\left\{{ }^{1} \mathrm{H}\right\}-\mathrm{APT}$ NMR plus HSQC and HMBC (75 MHz, benzene- $\left.d_{6}, 298 \mathrm{~K}\right): \delta 181.6$ (s, $\left.\mathrm{C}_{\mathrm{q}}-\mathrm{COO}\right), 145.5\left(\mathrm{~s}, \mathrm{C}_{\mathrm{q}}-\mathrm{Ph}\right), 140.7\left(\mathrm{~d},{ }^{3} J_{\mathrm{C}-\mathrm{P}}=12.8, \mathrm{C}_{\mathrm{q}} \mathrm{Ph}\right), 117.4$ $(\mathrm{s}, \mathrm{Ph}), 116.6(\mathrm{~s}, \mathrm{Ph}), 108.6(\mathrm{~s}, \mathrm{Ph}), 107.4(\mathrm{~s}, \mathrm{Ph}), 37.2\left(\mathrm{~d},{ }^{1} J_{\mathrm{C}-\mathrm{P}}=\right.$ 22.7, $\left.\mathrm{C}_{\mathrm{q}}-\mathrm{P}^{t} \mathrm{Bu}_{2}\right), 36.3\left(\mathrm{~d},{ }^{1} J_{\mathrm{C}-\mathrm{P}}=17.7, \mathrm{C}_{\mathrm{q}}-\mathrm{P}^{t} \mathrm{Bu}_{2}\right), 32.7\left(\mathrm{~s}, \mathrm{NCH}_{3}\right)$, $31.4\left(\mathrm{~d},{ }^{1} J_{\mathrm{C}-\mathrm{P}}=26.5 \mathrm{~Hz}, \mathrm{NCH}_{2}\right), 29.6\left(\mathrm{dd},{ }^{2} J_{\mathrm{C}-\mathrm{P}}=25.4,{ }^{4} J_{\mathrm{C}-\mathrm{P}}=3.4\right.$, $\left.\mathrm{CH}_{3}{ }^{-} \mathrm{Bu}\right), 27.0\left(\mathrm{~d},{ }^{1} \mathrm{~J}_{\mathrm{C}-\mathrm{P}}=23.4, \mathrm{CH}\left(\mathrm{CH}_{3}\right)_{2}\right), 20.3\left(\mathrm{~d},{ }^{2} \mathrm{~J}_{\mathrm{C}-\mathrm{P}}=17.1\right.$, $\left.\mathrm{CH}\left(\mathrm{CH}_{3}\right)_{2}\right), 19.8$ (s, $\left.\mathrm{CH}_{3} \mathrm{COO}\right)$.

Reaction of $\mathbf{2}$ with Formic Acid: Characterization of $\mathbf{5}$. Compound 2 ( $10 \mathrm{mg}, 0.0142 \mathrm{mmol})$ and formic acid $(0.7 \mathrm{mg}, 0.0156$ mmol, $0.6 \mu \mathrm{L})$ were dissolved in $0.5 \mathrm{~mL}$ of toluene- $d_{8}$ in a YoungNMR tube. ${ }^{1} \mathrm{H}$ NMR $\left(300 \mathrm{MHz}\right.$, toluene- $\left.d_{8}, 298 \mathrm{~K}\right): \delta 7.01(\mathrm{~m}, 2 \mathrm{H}$, $\mathrm{Ph}), 6.81(\mathrm{~m}, 2 \mathrm{H}, \mathrm{Ph}), 6.63(\mathrm{~s}, 1 \mathrm{H}, \mathrm{HCOO}), 3.43\left(\mathrm{~s}, 3 \mathrm{H}, \mathrm{NCH}_{3}\right)$, $3.21\left(\mathrm{dd},{ }^{2} J_{\mathrm{H}-\mathrm{P}}=12.1,{ }^{2} J_{\mathrm{H}-\mathrm{H}}=1.7,1 \mathrm{H}, \mathrm{NCH}_{2}\right), 2.49\left(\mathrm{dd},{ }^{2} J_{\mathrm{H}-\mathrm{P}}=\right.$ $\left.12.3,{ }^{2} J_{\mathrm{H}-\mathrm{H}}=1.7,1 \mathrm{H}, \mathrm{NCH}_{2}\right), 1.74\left(\mathrm{~m}, 3 \mathrm{H}, \mathrm{PCH}\left(\mathrm{CH}_{3}\right)_{2}\right), 1.18(\mathrm{dd}$, $\left.{ }^{3} J_{\mathrm{H}-\mathrm{P}}=12.6,{ }^{3} J_{\mathrm{H}-\mathrm{H}}=6.9,9 \mathrm{H}, \mathrm{PCH}\left(\mathrm{CH}_{3}\right)_{2}\right), 1.12\left(\mathrm{~d},{ }^{3} J_{\mathrm{H}-\mathrm{P}}=12.7\right.$, $\left.9 \mathrm{H}, \mathrm{P}^{t} \mathrm{Bu}\right), 1.05\left(\mathrm{dd},{ }^{3} J_{\mathrm{H}-\mathrm{P}}=12.8,{ }^{3} J_{\mathrm{H}-\mathrm{H}}=6.9,9 \mathrm{H}, \mathrm{PCH}\left(\mathrm{CH}_{3}\right)_{2}\right)$, $0.96\left(\mathrm{~d},{ }^{3} \mathrm{~J}_{\mathrm{H}-\mathrm{P}}=12.1,9 \mathrm{H}, \mathrm{P}^{t} \mathrm{Bu}\right),-11.73\left(\mathrm{br}, 3 \mathrm{H}, \mathrm{OsH}_{3}\right) .{ }^{1} \mathrm{H}$ NMR (300 MHz, toluene- $d_{8}, 183 \mathrm{~K}$, high-field region): $\delta-4.16$ (br s, $1 \mathrm{H}$, $\mathrm{OsH}),-15.66\left(\mathrm{AB}\right.$ system, $\Delta \nu=1175 \mathrm{~Hz}, J_{\mathrm{A}-\mathrm{B}}=153.0 \mathrm{~Hz}, 2 \mathrm{H}$, $\left.\mathrm{OsH}_{2}\right) . T_{1}(\mathrm{~min})\left(\mathrm{ms}, \mathrm{Os}-\mathrm{H}, 300 \mathrm{MHz}\right.$, toluene- $\left.d_{8}, 223 \mathrm{~K}\right): 64 \pm 6$ $(-17.28 \mathrm{ppm})$; the $T_{1}(\mathrm{~min})$ value of the resonance at $-4.32 \mathrm{ppm}$ could not be calculated due to its broadness. ${ }^{31} \mathrm{P}\left\{{ }^{1} \mathrm{H}\right\}$ NMR (121 $\mathrm{MHz}$, toluene- $\left.d_{8}, 298 \mathrm{~K}\right): \delta 84.1\left(\mathrm{~d},{ }^{2} J_{\mathrm{P}-\mathrm{P}}=234.6\right), 48.3\left(\mathrm{~d},{ }^{2} J_{\mathrm{P}-\mathrm{P}}=\right.$ 234.6). ${ }^{13} \mathrm{C}\left\{{ }^{1} \mathrm{H}\right\}-\mathrm{APT}$ NMR plus HSQC and HMBC $(75 \mathrm{MHz}$, toluene- $\left.d_{8}, 298 \mathrm{~K}\right): \delta 173.2(\mathrm{~s}, \mathrm{HCOO}), 145.5\left(\mathrm{~s}, \mathrm{C}_{\mathrm{q}} \mathrm{Ph}\right), 140.7(\mathrm{~d}$, $\left.{ }^{3} J_{\mathrm{C}-\mathrm{P}}=12.9, \mathrm{C}_{\mathrm{q}}-\mathrm{Ph}\right), 117.9(\mathrm{~s}, \mathrm{Ph}), 117.0(\mathrm{~s}, \mathrm{Ph}), 108.9(\mathrm{~s}, \mathrm{Ph}), 107.8$ $(\mathrm{s}, \mathrm{Ph}), 37.6\left(\mathrm{~d},{ }^{1} J_{\mathrm{C}-\mathrm{P}}=22.7, \mathrm{C}_{\mathrm{q}}{ }^{t} \mathrm{Bu}\right), 36.8\left(\mathrm{dd},{ }^{1} J_{\mathrm{C}-\mathrm{P}}=18.3,{ }^{3} J_{\mathrm{C}-\mathrm{P}}=\right.$ 2.8, $\left.\mathrm{C}_{\mathrm{q}}{ }^{t} \mathrm{Bu}\right), 33.0\left(\mathrm{~s}, \mathrm{NCH}_{3}\right), 31.4\left(\mathrm{~d},{ }^{1} J_{\mathrm{C}-\mathrm{P}}=26.5, \mathrm{NCH}_{2}\right), 29.8(\mathrm{dd}$, $\left.{ }^{3} J_{\mathrm{C}-\mathrm{P}}=12.4,{ }^{5} J_{\mathrm{C}-\mathrm{P}}=3.3, \mathrm{CH}_{3}{ }^{t} \mathrm{Bu}\right), 27.0\left(\mathrm{dd},{ }^{1} J_{\mathrm{C}-\mathrm{P}}=23.7,{ }^{3} J_{\mathrm{C}-\mathrm{P}}=\right.$ 1.9, $\left.\mathrm{CH}\left(\mathrm{CH}_{3}\right)_{2}\right), 20.4\left(\mathrm{~s}, \mathrm{CH}\left(\mathrm{CH}_{3}\right)_{2}\right)$.

General Procedure for the Formic Acid Dehydrogenation Studies. The progress of the reaction was monitored using a reactor equipped with a pressured transducer (Man on the Moon series X103 kit; https://www.manonthemoontech.com/x102-gas-evolution.html).
The total volume of the reactor was $18.8 \mathrm{~mL}$. The procedure employed was as follows: under an argon atmosphere, a solution of 2 in $1 \mathrm{~mL}$ of toluene was incorporated into the reactor, which was closed and placed in an oil bath at the desired temperature. Then, the pressure was monitored until a stable value was reached and the reactor tared. Subsequently the formic acid was injected through a septum cap. This moment was considered the initial time of the catalysis. The reaction was followed by measuring the total pressure as a function of the time.

NMR Spectroscopic Studies of the Decarboxylation of Complex 5. The decarboxylation of complex $\mathbf{5}$ was monitored by ${ }^{31} \mathrm{P}\left\{{ }^{1} \mathrm{H}\right\}$ NMR spectroscopy $(162.0 \mathrm{MHz})$. NMR spectra were acquired in a temperature range from 318 to $338 \mathrm{~K}$ at different times. A $0.5 \mathrm{~mL}$ portion of a $0.0142 \mathrm{M}$ solution of 2 in toluene- $d_{8}$ was placed in a Young NMR tube with a capillary containing a solution of $\mathrm{PPh}_{3}$ as an internal standard. The addition of $10 \mu \mathrm{L}$ of a $0.7 \mathrm{M}$ solution of $\mathrm{HCOOH}$ afforded the instantaneous formation of 5. The ${ }^{31} \mathrm{P}\left\{{ }^{1} \mathrm{H}\right\}$ NMR parameters were modified as follows for the integration of the signal: pulse program (zgig30), $d_{1} \geq 5 T_{1}\left(d_{1}=33 \mathrm{~s}\right)$. Prior to the study, the relaxation times of $\mathbf{2}, \mathbf{5}$, and $\mathrm{PPh}_{3}$ were determined by varying the delay times.

\section{ASSOCIATED CONTENT}

\section{Supporting Information}

The Supporting Information is available free of charge at https://pubs.acs.org/doi/10.1021/acs.inorgchem.1c02893.

General information, structural analysis of complexes 2 and 5, computational data, and NMR spectra (PDF)

Cartesian coordinates of computed complexes (XYZ)

\section{Accession Codes}

CCDC 2096535-2096536 contain the supplementary crystallographic data for this paper. These data can be obtained free of charge via www.ccdc.cam.ac.uk/data request/cif, or by emailing data_request@ccdc.cam.ac.uk, or by contacting The Cambridge Crystallographic Data Centre, 12 Union Road, Cambridge CB2 1EZ, UK; fax: +44 1223336033.

\section{AUTHOR INFORMATION}

\section{Corresponding Author}

Miguel A. Esteruelas - Departamento de Química Inorgánica, Instituto de Sintesis Química y Catálisis Homogénea (ISQCH), Centro de Innovación en Química Avanzada (ORFEO-CINQA), Universidad de Zaragoza-CSIC, 50009 Zaragoza, Spain; 이이.org/0000-0002-4829-7590; Email: maester@unizar.es

\section{Authors}

María L. Buil - Departamento de Química Inorgánica, Instituto de Síntesis Química y Catálisis Homogénea (ISQCH), Centro de Innovación en Química Avanzada (ORFEO-CINQA), Universidad de Zaragoza-CSIC, 50009 Zaragoza, Spain; 이이.org/0000-0002-3284-1053

Javier A. Cabeza - Departamento de Química Orgánica e Inorgánica, Centro de Innovación en Química Avanzada (ORFEO-CINQA), Universidad de Oviedo, 33071 Oviedo, Spain; orcid.org/0000-0001-8563-9193

Susana Izquierdo - Departamento de Química Inorgánica, Instituto de Síntesis Química y Catálisis Homogénea (ISQCH), Centro de Innovación en Química Avanzada (ORFEO-CINQA), Universidad de Zaragoza-CSIC, 50009 Zaragoza, Spain; 이이.org/0000-0002-6608-1910

Carlos J. Laglera-Gándara - Departamento de Química Orgánica e Inorgánica, Centro de Innovación en Química 
Avanzada (ORFEO-CINQA), Universidad de Oviedo, 33071 Oviedo, Spain

Antonio I. Nicasio - Departamento de Química Inorgánica, Instituto de Sintesis Química y Catálisis Homogénea (ISQCH), Centro de Innovación en Quimica Avanzada (ORFEO-CINQA), Universidad de Zaragoza-CSIC, 50009 Zaragoza, Spain; ๑ orcid.org/0000-0002-2268-4920

Enrique Oñate - Departamento de Química Inorgánica, Instituto de Sintesis Química y Catálisis Homogénea (ISQCH), Centro de Innovación en Química Avanzada (ORFEO-CINQA), Universidad de Zaragoza-CSIC, 50009 Zaragoza, Spain; ๑ orcid.org/0000-0003-2094-719X

Complete contact information is available at:

https://pubs.acs.org/10.1021/acs.inorgchem.1c02893

\section{Notes}

The authors declare no competing financial interest.

\section{ACKNOWLEDGMENTS}

Financial support was provided by the MICINN of Spain (PID2020-115286GB-I00/AEI/10.13039/501100011033, RED2018-102387-T, and PID2019-104652GB-I00), Gobierno de Aragón (E06_20R and LMP148_18), FEDER, and FSE.

\section{REFERENCES}

(1) (a) Grützmacher, H. Cooperating Ligands in Catalysis. Angew. Chem., Int. Ed. 2008, 47, 1814-1818. (b) Khusnutdinova, J. R.; Milstein, D. Metal-Ligand Cooperation. Angew. Chem., Int. Ed. 2015, 54, 12236-12273. (c) Feichtner, K.-S.; Gessner, V. H. Cooperative Bond Activation Reactions with Carbene Complexes. Chem. Commun. 2018, 54, 6540-6553. (d) Higashi, T.; Kusumoto, S.; Nozaki, K. Cleavage of $\mathrm{Si}-\mathrm{H}, \mathrm{B}-\mathrm{H}$, and $\mathrm{C}-\mathrm{H}$ Bonds by Metal-Ligand Cooperation. Chem. Rev. 2019, 119, 10393-10402. (e) Shimbayashi, T.; Fujita, K. Recent Advances in Homogeneous Catalysis via MetalLigand Cooperation Involving Aromatization and Dearomatization. Catalysts 2020, 10, 635-703. (f) Roy, B. C.; Ganguli, K.; Samim, S. A.; Kundu, S. Alkyl Phosphine Free, Metal-Ligand Cooperative Complex Catalyzed Alcohol Dehydrogenative Coupling Reactions. Asian J. Org. Chem. 2021, 10, 1218-1232.

(2) Shvo, Y.; Czarkie, D.; Rahamim, Y.; Chodosh, D. F. A New Group of Ruthenium Complexes: Structure and Catalysis. J. Am. Chem. Soc. 1986, 108, 7400-7402.

(3) Fujita, K.; Tanino, N.; Yamaguchi, R. Ligand-Promoted Dehydrogenation of Alcohols Catalyzed by $\mathrm{Cp} * \mathrm{Ir}$ Complexes. A New Catalytic System for Oxidant-Free Oxidation of Alcohols. Org. Lett. 2007, 9, 109-111.

(4) Noyori, R.; Hashiguchi, S. Asymmetric Transfer Hydrogenation Catalyzed by Chiral Ruthenium Complexes. Acc. Chem. Res. 1997, 30, 97-102.

(5) (a) Zhang, J.; Leitus, G.; Ben-David, Y.; Milstein, D. Facile Conversion of Alcohols into Esters and Dihydrogen Catalyzed by New Ruthenium Complexes. J. Am. Chem. Soc. 2005, 127, 1084010841. (b) Gunanathan, C.; Milstein, D. Metal-Ligand Cooperation by Aromatization-Dearomatization: A New Paradigm in Bond Activation and "Green" Catalysis. Acc. Chem. Res. 2011, 44, 588602. (c) Gunanathan, C.; Milstein, D. Applications of Acceptorless Dehydrogenation and Related Transformations in Chemical Synthesis. Science 2013, 341, 1229712. (d) Gunanathan, C.; Milstein, D. Bond Activation and Catalysis by Ruthenium Pincer Complexes. Chem. Rev. 2014, 114, 12024-12087. (e) Zell, T.; Milstein, D. Hydrogenation and Dehydrogenation Iron Pincer Catalysts Capable of Metal-Ligand Cooperation by Aromatization/Dearomatization. Acc. Chem. Res. 2015, 48, 1979-1994.

(6) (a) Bouhadir, G.; Bourissou, D. Complexes of Ambiphilic Ligands: Reactivity and Catalytic Applications. Chem. Soc. Rev. 2016, 45, 1065-1079. (b) Chatterjee, B.; Chang, W.-C.; Jena, S.; Werlé, C.
Implementation of Cooperative Designs in Polarized Transition Metal Systems-Significance for Bond Activation and Catalysis. ACS Catal. 2020, 10, 14024-14055. (c) Elsby, M. R.; Baker, R. T. Strategies and Mechanisms of Metal-Ligand Cooperativity in First-Row Transition Metal Complex Catalysts. Chem. Soc. Rev. 2020, 49, 8933-8987.

(7) (a) Devillard, M.; Bouhadir, G.; Bourissou, D. Cooperation between Transition Metals and Lewis Acids: A Way To Activate $\mathrm{H}_{2}$ and $\mathrm{H}-\mathrm{E}$ bonds. Angew. Chem., Int. Ed. 2015, 54, 730-732. (b) Jones, J. S.; Gabbaï, F. P. Coordination- and Redox-Noninnocent Behavior of Ambiphilic Ligands Containing Antimony. Acc. Chem. Res. 2016, 49, 857-867. (c) Owen, G. R. Functional Group Migrations between Boron and Metal Centres within Transition Metal-Borane and Boryl Complexes and Cleavage of $\mathrm{H}-\mathrm{H}, \mathrm{E}-\mathrm{H}$ and $\mathrm{E}-\mathrm{E}^{\prime}$ Bonds. Chem. Commun. 2016, 52, 10712-10726.

(8) Green, M. L. H. A New Approach to the Formal Classification of Covalent Compounds of the elements. J. Organomet. Chem. 1995, $500,127-148$

(9) Fong, H.; Moret, M.-E.; Lee, Y.; Peters, J. C. Heterolytic $\mathrm{H}_{2}$ Cleavage and Catalytic Hydrogenation by an Iron Metallaboratrane. Organometallics 2013, 32, 3053-3062.

(10) (a) Lin, T.-P.; Peters, J. C. Boryl-Mediated Reversible $\mathrm{H}_{2}$ Activation at Cobalt: Catalytic Hydrogenation, Dehydrogenation, and Transfer Hydrogenation. J. Am. Chem. Soc. 2013, 135, 15310-15313. (b) Ganguly, G.; Malakar, T.; Paul, A. Theoretical Studies on the Mechanism of Homogeneous Catalytic Olefin Hydrogenation and Amine-Borane Dehydrogenation by a Versatile Boryl-Ligand-Based Cobalt Catalyst. ACS Catal. 2015, 5, 2754-2769. (c) Nesbit, M. A.; Suess, D. L. M.; Peters, J. C. E-H Bond Activations and Hydrosilylation Catalysis with Iron and Cobalt Metalloboranes. Organometallics 2015, 34, 4741-4752.

(11) (a) Fontaine, F.-G.; Zargarian, D. $\mathrm{Me}_{2} \mathrm{AlCH}_{2} \mathrm{PMe}_{2}$ : A New, Bifunctional Cocatalyst for the $\mathrm{Ni}(\mathrm{II})$-Catalyzed Oligomerization of $\mathrm{PhSiH}_{3}$. J. Am. Chem. Soc. 2004, 126, 8786-8794. (b) Harman, W. H.; Peters, J. C. Reversible $\mathrm{H}_{2}$ Addition across a Nickel-Borane Unit as a Promising Strategy for Catalysis. J. Am. Chem. Soc. 2012, 134, 5080-5082. (c) MacMillan, S. N.; Harman, W. H.; Peters, J. C. Facile $\mathrm{Si}-\mathrm{H}$ Bond Activation and Hydrosilylation Catalysis Mediated by a Nickel-Borane Complex. Chem. Sci. 2014, 5, 590-597. (d) Cammarota, R. C.; Lu, C. C. Tuning Nickel with Lewis Acidic Group 13 Metalloligands for Catalytic Olefin Hydrogenation. J. Am. Chem. Soc. 2015, 137, 12486-12489. (e) Cammarota, R. C.; Vollmer, M. V.; Xie, J.; Ye, J.; Linehan, J. C.; Burgess, S. A.; Appel, A. M.; Gagliardi, L.; Lu, C. C. A Bimetallic Nickel-Gallium Complex Catalyzes $\mathrm{CO}_{2}$ Hydrogenation via the Intermediacy of an Anionic $\mathrm{d}^{10}$ Nickel Hydride. J. Am. Chem. Soc. 2017, 139, 14244-14250. (f) Ramirez, B. L.; Lu, C. C. Rare-Earth Supported Nickel Catalysts for Alkyne Semihydrogenation: Chemo- and Regioselectivity Impacted by the Lewis Acidity and Size of the Support. J. Am. Chem. Soc. 2020, 142, 5396-5407.

(12) Yamada, R.; Iwasawa, N.; Takaya, J. Rhodium-Catalyzed C-H Activation Enabled by an Indium Metallo-ligand. Angew. Chem., Int. Ed. 2019, 58, 17251-17254.

(13) (a) Kameo, H.; Yamamoto, J.; Asada, A.; Nakazawa, H.; Matsuzaka, H.; Bourissou, D. Palladium-Borane Cooperation: Evidence for an Anionic Pathway and Its Application to Catalytic Hydro-/Deutero-dechlorination. Angew. Chem., Int. Ed. 2019, 58, 18783-18787. (b) Kameo, H.; Yamamoto, H.; Ikeda, K.; Isasa, T.; Sakaki, S.; Matsuzakka, H.; García-Rodeja, Y.; Miqueu, K.; Bourissou, D. Fluorosilane Activation by $\mathrm{Pd} / \mathrm{Ni} \rightarrow \mathrm{Si}-\mathrm{F} \rightarrow$ Lewis Acid Interaction: An Entry to Catalytic Sila-Negishi Coupling. J. Am. Chem. Soc. 2020, 142, 14039-14044.

(14) You, D.; Gabbai, F. P. Unmasking the Catalytic Activity of a Platinum Complex with a Lewis Acidic, Non-innocent Antimony Ligand. J. Am. Chem. Soc. 2017, 139, 6843-6846.

(15) (a) Devillard, M.; Nicolas, E.; Appelt, C.; Backs, J.; MalletLadeira, S.; Bouhadir, G.; Slootweg, J. C.; Uhl, W.; Bourissou, D. Novel Zwitterionic Complexes Arising from the Coordination of an Ambiphilic Phosphorus-Aluminum ligand to Gold. Chem. Commun. 2014, 50, 14805-14808. (b) Inagaki, F.; Matsumoto, C.; Okada, Y.; 
Maruyama, N.; Mukai, C. Air-Stable Cationic Gold(I) Catalyst Featuring a Z-Type Ligand: Promoting Enyne Cyclizations. Angew. Chem., Int. Ed. 2015, 54, 818-822. (c) Yang, H.; Gabbai, F. P. Activation pf a Hydroamination Gold Catalyst by Oxidation of a Redox-Noninnocent Chlorostibine Z-ligand. J. Am. Chem. Soc. 2015, 137, 13425-13432. (d) Ueno, A.; Watanabe, K.; Daniliuc, C. G.; Kehr, G.; Erke, G. Unsaturated Vicinal Frustrated Phosphane/Borane Lewis Pairs as ligands in Gold(I) Chemistry. Chem. Commun. 2019, 55, 4367-4370.

(16) Esteruelas, M. A.; López, A. M.; Oliván, M. Polyhydrides of Platinum Group Metals: Nonclassical Interactions and $\sigma$-Bond Activation Reactions. Chem. Rev. 2016, 116, 8770-8847.

(17) (a) Barrio, P.; Esteruelas, M. A.; Oñate, E. Reactions of a Hexahydride-Osmium Complex with Aldehydes: Double $\mathrm{C}-\mathrm{H}_{\alpha}$ Activation-Decarbonylation and Single $\mathrm{C}-\mathrm{H}_{\alpha}$ Activation-Hydroxylation Tandem Processes and Catalytic Tishchenko Reactions. Organometallics 2004, 23, 1340-1348. (b) Eguillor, B.; Esteruelas, M. A.; García-Raboso, J.; Oliván, M.; Oñate, E. Stoichiometric and Catalytic Deuteration of Pyridine and Methylpyridines by H/D Exchange with Benzene- $d_{6}$ Promoted by an Unsaturated Osmium Tetrahydride Species. Organometallics 2009, 28, 3700-3709. (c) Esteruelas, M. A.; Honczek, N.; Oliván, M.; Oñate, E.; Valencia, M. Direct Access to POP-Type Osmium(II) and Osmium(IV) Complexes: Osmium a Promising Alternative to Ruthenium for the Synthesis of Imines from Alcohols and Amines. Organometallics 2011, 30, 2468-2471. (d) Bertoli, M.; Choualeb, A.; Gusev, D. G.; Lough, A. J.; Major, Q.; Moore, B. PNP Pincer Osmium Polyhydrides for Catalytic Dehydrogenation of Primary Alcohols. Dalton Trans. 2011, 40, 8941-8949. (e) Alós, J.; Bolaño, T.; Esteruelas, M. A.; Oliván, M.; Oñate, E.; Valencia, M. POP-Pincer Osmium-Polyhydrides: Head-toHead (Z)-Dimerization of Terminal Alkynes. Inorg. Chem. 2013, 52, 6199-6213. (f) Babón, J. C.; Esteruelas, M. A.; Fernández, I.; López, A. M.; Oñate, E. Dihydroboration of Alkyl Nitriles Catalyzed by an Osmium-Polyhydride: Scope, Kinetics, and Mechanism. Organometallics 2020, 39, 3864-3872. (g) Babón, J. C.; Esteruelas, M. A.; López, A. M.; Oñate, E. Osmium-Promoted Transformation of Alkyl Nitriles to Secondary Aliphatic Amines: Scope and Mechanism. Organometallics 2020, 39, 2177-2188. (h) Babón, J. C.; Esteruelas, M. A.; López, A. M.; Oñate, E. Hydration of Aliphatic Nitriles Catalyzed by an Osmium Polyhydride: Evidence for an Alternative Mechanism. Inorg. Chem. 2021, 60, 7284-7296.

(18) (a) Esteruelas, M. A.; Lezaún, V.; Martínez, A.; Oliván, M.; Oñate, E. Osmium Hydride Acetylacetonate Complexes and Their Application in Acceptorless Dehydrogenative Coupling of Alcohols and Amines and for the Dehydrogenation of Cyclic Amines. Organometallics 2017, 36, 2996-3004. (b) Esteruelas, M. A.; García-Yebra, C.; Martín, J.; Oñate, E. Dehydrogenation of Formic Acid Promoted by a Trihydride-Hydroxo-Osmium(IV) Complex: Kinetics and Mechanism. ACS Catal. 2018, 8, 11314-11323. (c) Buil, M. L.; Esteruelas, M. A.; Gay, M. P.; Gómez-Gallego, M.; Nicasio, A. I.; Oñate, E.; Santiago, A.; Sierra, M. A. Osmium Catalyst for Acceptorless and Base-Free Dehydrogenation of Alcohols and Amines: Unusual Coordination Modes of a BPI Anion. Organometallics 2018, 37, 603-617. (d) Buil, M. L.; Esteruelas, M. A.; Izquierdo, S.; Nicasio, A. I.; Oñate, $\mathrm{E} . \mathrm{N}-\mathrm{H}$ and $\mathrm{C}-\mathrm{H}$ Bond Activations of an Isoindoline Promoted by Iridium- and OsmiumPolyhydride Complexes: A Noninnocent Bridge Ligand for Acceptorless and Base-Free Dehydrogenation of Secondary Alcohols. Organometallics 2020, 39, 2719-2731.

(19) Esteruelas, M. A.; López, A. M.; Mora, M.; Oñate, E. AmmoniaBorane Dehydrogenation Promoted by an Osmium Dihydride Complex: Kinetics and Mechanism. ACS Catal. 2015, 5, 187-191.

(20) (a) Baumgartner, J.; Marschner, C. Coordination of NonStabilized Germylenes, Stannylenes, and Plumbylenes to Transition Metals. Rev. Inorg. Chem. 2014, 34, 119-152. (b) Álvarez-Rodríguez, L.; Cabeza, J. A.; García-Álvarez, P.; Polo, D. The Transition-Metal Chemistry of Amidinatosilylenes, -Germylenes and -Stannylenes. Coord. Chem. Rev. 2015, 300, 1-28. (c) Cabeza, J. A.; García-Álvarez, P.; Laglera-Gándara, C. J. The Transition Metal Chemistry of PGeP and PSnP Pincer Heavier Tetrylenes. Eur. J. Inorg. Chem. 2020, 2020, 784-795. (d) Somerville, R. J.; Campos, J. Cooperativity in Transition Metal Tetrylene Complexes. Eur. J. Inorg. Chem. 2021, 2021, 3488-3498.

(21) Pandey, K. K.; Power, P. P. Nature of M-E Bonds in Metallosilylenes, -Germylenes, -Stannylenes, and -Plumbylenes [ $\left(\eta^{5}\right.$ $\left.\left.\mathrm{C}_{5} \mathrm{H}_{5}\right)\left(\mathrm{Me}_{3} \mathrm{P}\right)(\mathrm{H})_{2} \mathrm{M}(\mathrm{EPh})\right](\mathrm{M}=\mathrm{Fe}, \mathrm{Ru}, \mathrm{Os} ; \mathrm{E}=\mathrm{Si}, \mathrm{Ge}, \mathrm{Sn}, \mathrm{Pb})$. Organometallics 2011, 30, 3353-3361.

(22) Cabeza, J. A.; García-Álvarez, P.; Polo, D. Intramolecularly Stabilized Heavier Tetrylenes: From Monodentate to Bidentate Ligands. Eur. J. Inorg. Chem. 2016, 2016, 10-22.

(23) (a) Grasemann, M.; Laurenczy, G. Formic Acid as a Hydrogen Source - Recent Developments and Future Trends. Energy Environ. Sci. 2012, 5, 8171-8181. (b) He, T.; Pachfule, P.; Wu, H.; Xu, Q.; Chen, P. Hydrogen Carriers. Nat. Rev. Mater. 2016, 1, 16067. (c) Kawanami, H.; Himeda, Y.; Laurenczy, G. Formic Acid as a Hydrogen Carrier for Fuel Cells Toward a Sustainable Energy System. Adv. Inorg. Chem. 2017, 70, 395-427. (d) Eppinger, J.; Huang, K.-W. Formic Acid as a Hydrogen Energy Carrier. ACS Energy Lett. 2017, 2, $188-195$.

(24) (a) Singh, A. K.; Singh, S.; Kumar, A. Hydrogen Energy Future with Formic Acid: a Renewable Chemical Hydrogen Storage System. Catal. Sci. Technol. 2016, 6, 12-40. (b) Mellmann, D.; Sponholz, P.; Junge, H.; Beller, M. Formic Acid as a Hydrogen Storage Material Development of Homogeneous Catalysts for Selective Hydrogen Release. Chem. Soc. Rev. 2016, 45, 3954-3988. (c) Sordakis, K.; Tang, C.; Vogt, L. K.; Junge, H.; Dyson, P. J.; Beller, M.; Laurenczy, G. Homogeneous Catalysis for Sustainable Hydrogen Storage in Formic Acid and Alcohols. Chem. Rev. 2018, 118, 372-433. (d) Wang, X.; Meng, Q.; Gao, L.; Jin, Z.; Ge, J.; Liu, C.; Xing, W. Recent Progress in Hydrogen Production from Formic Acid Decomposition. Int. J. Hydrogen Energy 2018, 43, 7055-7071. (e) Onishi, N.; Laurenczy, G.; Beller, M.; Himeda, Y. Recent Progress for Reversible Homogeneous Catalytic Hydrogen Storage in Formic Acid and in Methanol. Coord. Chem. Rev. 2018, 373, 317-332. (f) Stathi, P.; Solakidou, M.; Louloudi, M.; Deligiannakis, Y. From Homogeneous to Heterogenized Molecular Catalysts for $\mathrm{H}_{2}$ Production by Formic Acid Dehydrogenation: Mechanistic Aspects, Role of Additives, and CoCatalysts. Energies 2020, 13, 733.

(25) Iglesias, M.; Oro, L. A. Mechanistic Considerations on Homogeneously Catalyzed Formic Acid Dehydrogenation. Eur. J. Inorg. Chem. 2018, 2018, 2125-2138.

(26) (a) Barnard, J. H.; Wang, C.; Berry, N. G.; Xiao, J. Long-Range Metal-Ligand Bifunctional Catalysis: Cyclometallated Iridium Catalysts for the Mild and Rapid Dehydrogenation of Formic Acid. Chem. Sci. 2013, 4, 1234-1244. (b) Matsunami, A.; Kayaki, Y.; Ikariya, T. Enhanced Hydrogen Generation from Formic Acid by Half-Sandwich Iridium(III) Complexes with Metal/NH Bifunctionality: A Pronounced Switch from Transfer Hydrogenation. Chem. Eur. J. 2015, 21, 13513-13517. (c) Iguchi, M.; Zhong, H.; Himeda, Y.; Kawanami, H. Kinetic Studies on Formic Acid Dehydrogenation Catalyzed by an Iridium Complex towards Insights into the Catalytic Mechanism of High-Pressure Hydrogen Gas Production. Chem. - Eur. J. 2017, 23, 17017-17021. (d) Cohen, S.; Borin, V.; Schapiro, I.; Musa, S.; De-Botton, S.; Belkova, N. V.; Gelman, D. Ir(III)-PC( $\left.\mathrm{sp}^{3}\right) \mathrm{P}$ Bifunctional Catalysts for Production of $\mathrm{H}_{2}$ by Dehydrogenation of Formic Acid: Experimental and Theoretical Study. ACS Catal. 2017, 7, 8139-8146. (e) Singh, A.; Gelman, D. Cooperative Reactivity in Carbometalated Pincer-Type Complexes Possessing an Appended Functionality. ACS Catal. 2020, 10, 1246-1255.

(27) (a) Alvarez-Rodríguez, L.; Brugos, J.; Cabeza, J. A.; GarcíaÁlvarez, P.; Pérez-Carreño, E.; Polo, D. Synthesis and Initial Transition Metal Chemistry of the First PGeP Pincer-Type Germylene. Chem. Commun. 2017, 53, 893-896. (b) ÁlvarezRodríguez, L.; Brugos, J.; Cabeza, J. A.; García-Álvarez, P.; PérezCarreño, E. From a Diphosphanegermylene to Nickel, Palladium, and Platinum Complexes Containing Germyl PGeP Pincer Ligands. Chem. - Eur. J. 2017, 23, 15107-15115. (c) Brugos, J.; Cabeza, J. A.; GarcíaÁlvarez, P.; Pérez-Carreño, E.; Polo, D. Synthesis and Some 
Coordination Chemistry of the PSnP Pincer-Type Stannylene $\mathrm{Sn}\left(\mathrm{NCH}_{2} \mathrm{P}^{t} \mathrm{Bu}_{2}\right)_{2} \mathrm{C}_{6} \mathrm{H}_{4}$, Attempts to Prepare the PSiP Analogue, and the Effect of the $\mathrm{E}$ Atom on the Molecular Structures of $\mathrm{E}\left(\mathrm{NCH}_{2} \mathrm{P}^{t} \mathrm{Bu}_{2}\right)_{2} \mathrm{C}_{6} \mathrm{H}_{4}(\mathrm{E}=\mathrm{C}, \mathrm{Si}, \mathrm{Ge}, \mathrm{Sn})$. Dalton Trans. 2018, 47, 4534-4544. (d) Brugos, J.; Cabeza, J. A.; García-Álvarez, P.; PérezCarreño, E. From a PGeP Pincer-Type Germylene to Metal Complexes Featuring Chelating (Ir) and Tripodal (Ir) PGeP Germyl and Bridging $\left(\mathrm{Mn}_{2}\right)$ and Chelating $(\mathrm{Ru})$ PGeP Germylene Ligands. Organometallics 2018, 37, 1507-1514.

(28) Garrou, P. E. Transition-Metal-Mediated Phosphorus-Carbon Bond Cleavage and its Relevance to Homogeneous Catalyst Deactivation. Chem. Rev. 1985, 85, 171-185.

(29) (a) Sakamoto, M.; Shimizu, I.; Yamamoto, A. PalladiumCatalyzed Cleavage of P-C Bonds in Quaternary Phosphonium Salts and Its Applications to Organic Synthesis. Chem. Lett. 1995, 24, 1101-1102. (b) Wang, L.; Chen, H.; Duan, Z. Synthetic Applications of Transition- Metal-Catalyzed C-P Bond Cleavage. Chem. - Asian J. 2018, 13, 2164-2173.

(30) See for example: (a) Alabau, R. G.; Eguillor, B.; Esler, J.; Esteruelas, M. A.; Oliván, M.; Oñate, E.; Tsai, J.-Y.; Xia, C. CCCPincer-NHC Osmium Complexes: New Types of Blue-Green Emissive Neutral Compounds for Organic Light-Emitting Devices (OLEDs). Organometallics 2014, 33, 5582-5596. (b) Cancela, L.; Esteruelas, M. A.; López, A. M.; Oliván, M.; Oñate, E.; San-Torcuato, A.; Vélez, A. Osmium- and Iridium-Promoted $\mathrm{C}-\mathrm{H}$ Bond Activation of 2,2'-Bipyridines and Related Heterocycles: Kinetic and Thermodynamic Preferences. Organometallics 2020, 39, 2102-2115. (c) Cancela, L.; Esteruelas, M. A.; Galbán, J.; Oliván, M.; Oñate, E.; Vélez, A.; Vidal, J. C. Electronic Communication in Binuclear Osmium- and Iridium-Polyhydrides. Inorg. Chem. 2021, 60, 2783-2796.

(31) (a) Babón, J. C.; Esteruelas, M. A.; Fernández, I.; López, A. M.; Oñate, E. Redox-Assisted Osmium-Promoted C-C Bond Activation of Alkylnitriles. Organometallics 2018, 37, 2014-2017. (b) Esteruelas, M. A.; Gay, M. P.; Oñate, E. Conceptual Extension of the Degradation-Transformation of N-Heterocyclic Carbenes: Unusual Rearrangements on Osmium. Organometallics 2018, 37, 3412-3424. (c) Valencia, M.; Merinero, A. D.; Lorenzo-Aparicio, C.; GómezGallego, M.; Sierra, M. A.; Eguillor, B.; Esteruelas, M. A.; Oliván, M.; Oñate, E. Osmium-Promoted $\sigma$-Bond Activation Reactions on Nucleosides. Organometallics 2020, 39, 312-323.

(32) (a) Esteruelas, M. A.; García-Raboso, J.; Oliván, M.; Oñate, E. $\mathrm{N}-\mathrm{H}$ and $\mathrm{N}-\mathrm{C}$ Bond Activation of Pyrimidinic Nucleobases and Nucleosides Promoted by an Osmium Polyhydride. Inorg. Chem. 2012, 51, 5975-5984. (b) Casarrubios, L.; Esteruelas, M. A.; Larramona, C.; Muntaner, J. G.; Oñate, E.; Sierra, M. A. 2Azetidinones as Precursors of Pincer Ligands: Preparation, Structure, and Spectroscopic Properties of $\mathrm{CC}^{\prime} \mathrm{N}-\mathrm{O}$ smium Complexes. Inorg. Chem. 2015, 54, 10998-11006. (c) Casarrubios, L.; Esteruelas, M. A.; Larramona, C.; Lledós, A.; Muntaner, J. G.; Oñate, E.; Ortuño, M. A.; Sierra, M. A. Mechanistic Insight into the Facilitation of $\beta$-Lactam Fragmentation through Metal Assistance. Chem. - Eur. J. 2015, 21, 16781-16785.

(33) Bolaño, T.; Esteruelas, M. A.; Gay, M. P.; Oñate, E.; Pastor, I. M.; Yus, M. An Acyl-NHC Osmium Cooperative System: Coordination of Small Molecules and Heterolytic B-H and $\mathrm{O}-\mathrm{H}$ Bond Activation. Organometallics 2015, 34, 3902-3908.

(34) Nie, P.; Yu, Q.; Zhu, H.; Wen, T.-B. Ruthenium and Osmium Germyl Complexes Derived from the Reactions of $\mathrm{MXCl}\left(\mathrm{PPh}_{3}\right)_{3}(\mathrm{M}$ $=\mathrm{Ru}, \mathrm{Os} ; \mathrm{X}=\mathrm{Cl}, \mathrm{H})$ with Terphenylchlorogermylene $\left(\mathrm{C}_{6} \mathrm{H}_{3}-2,6-\right.$ Trip $\left._{2}\right) \mathrm{GeCl}\left(\right.$ Trip $\left.=2,4,6-{ }^{i} \mathrm{Pr}_{3} \mathrm{C}_{6} \mathrm{H}_{2}\right)$. Eur. J. Inorg. Chem. 2017, 2017, 4784-4796.

(35) Castillo, A.; Esteruelas, M. A.; Oñate, E.; Ruiz, N. Dihydrido and Trihydrido Diolefin Complexes Stabilized by the $\mathrm{Os}\left(\mathrm{P}^{i} \mathrm{Pr}_{3}\right)_{2}$ Unit: New Examples of Quantum Mechanical Exchange Coupling in Trihydrido Osmium Compounds. J. Am. Chem. Soc. 1997, 119, 9691-9698.

(36) (a) Scholten, J. D.; Prechtl, M. H. G.; Dupont, J. Decomposition of Formic Acid Catalyzed by a Phosphine-Free Ruthenium Complex in a Task-Specific Ionic Liquid. ChemCatChem
2010, 2, 1265-1270. (b) Zell, T.; Butschke, B.; Ben-David, Y.; Milstein, D. Efficient Hydrogen Liberation from Formic Acid Catalyzed by a Well-Defined Iron Pincer Complex under Mild Conditions. Chem. - Eur. J. 2013, 19, 8068-8072. (c) Filonenko, G. A.; van Putten, R.; Schulpen, E. N.; Hensen, E. J. M.; Pidko, E. A. Highly Efficient Reversible Hydrogenation of Carbon Dioxide to Formates Using a Ruthenium PNP-Pincer Catalyst. ChemCatChem 2014, 6, 1526-1530. (d) Wang, W.-H.; Xu, S.; Manaka, Y.; Suna, Y.; Kambayashi, H.; Muckerman, J. T.; Fujita, E.; Himeda, Y. Formic Acid Dehydrogenation with Bioinspired Iridium Complexes: A Kinetic Isotope Effect Study and Mechanistic Insight. ChemSusChem 2014, 7, 1976-1983. (e) Wang, W.-H.; Ertem, M. Z.; Xu, S.; Onishi, N.; Manaka, Y.; Suna, Y.; Kambayashi, H.; Muckerman, J. T.; Fujita, E.; Himeda, Y. Highly Robust Hydrogen Generation by Bioinspired Ir Complexes for Dehydrogenation of Formic Acid in Water: Experimental and Theoretical Mechanistic Investigations at Different pH. ACS Catal. 2015, 5, 5496-5504. (f) Ertem, M. Z.; Himeda, Y.; Fujita, E.; Muckerman, J. T. Interconversion of Formic Acid and Carbon Dioxide by Proton-Responsive, Half-Sandwich Cp* Ir $^{\text {III }}$ Complexes: A Computational Mechanistic Investigation. ACS Catal. 2016, 6, 600-609.

(37) (a) Boddien, A.; Loges, B.; Gärtner, F.; Torborg, C.; Fumino, K.; Junge, H.; Ludwig, R.; Beller, M. Iron-Catalyzed Hydrogen Production from Formic Acid. J. Am. Chem. Soc. 2010, 132, 89248934. (b) Boddien, A.; Mellmann, D.; Gärtner, F.; Jackstell, R.; Junge, H.; Dyson, P. J.; Laurenczy, G.; Ludwig, R.; Beller, M. Efficient Dehydrogenation of Formic Acid Using an Iron Catalyst. Science 2011, 333, 1733-1736. (c) Pan, Y.; Pan, C.-L.; Zhang, Y.; Li, H.; Min, S.; Guo, X.; Zheng, B.; Chen, H.; Anders, A.; Lai, Z.; Zheng, J.; Huang, K.-W. Selective Hydrogen Generation from Formic Acid with Well-Defined Complexes of Ruthenium and Phosphorus-Nitrogen $\mathrm{PN}^{3}$-Pincer Ligand. Chem. - Asian J. 2016, 11, 1357-1360. (d) Iguchi, M.; Zhong, H.; Himeda, H.; Kawanami, H. Effect of the orthoHydroxyl Groups on a Bipyridine Ligand of Iridium Complexes for the High-Pressure Gas Generation from the Catalytic Decomposition of Formic Acid. Chem. - Eur. J. 2017, 23, 17788-17793. (e) Lu, S.-M.; Wang, Z.; Wang, J.; Lia, J.; Li, C. Hydrogen Generation from Formic Acid Decomposition on a Highly Efficient Iridium Catalyst Bearing a Diaminoglyoxime Ligand. Green Chem. 2018, 20, 1835-1840.

(38) (a) Myers, T. W.; Berben, L. A. Aluminium-Ligand Cooperation Promotes Selective Dehydrogenation of Formic Acid to $\mathrm{H}_{2}$ and $\mathrm{CO}_{2}$. Chem. Sci. 2014, 5, 2771-2777. (b) Mellone, I.; Bertini, F.; Peruzzini, M.; Gonsalvi, L. An Active, Stable and Recyclable Ru(II) Tetraphosphine-based Catalytic System for Hydrogen Production by Selective Formic Acid Dehydrogenation. Catal. Sci. Technol. 2016, 6, 6504-6512. (c) Mellone, I.; Gorgas, N.; Bertini, F.; Peruzzini, M.; Kirchner, K.; Gonsalvi, L. Selective Formic Acid Dehydrogenation Catalyzed by Fe-PNP Pincer Complexes Based on the 2,6-Diaminopyridine Scaffold. Organometallics 2016, 35, 33443349.

(39) Aracama, M.; Esteruelas, M. A.; Lahoz, F. J.; López, J. A.; Meyer, U.; Oro, L. A.; Werner, H. Synthesis, Reactivity, Molecular Structure, and Catalytic Activity of the Novel Dichlorodihydridoosmium(IV) Complexes $\mathrm{OsH}_{2} \mathrm{Cl}_{2}\left(\mathrm{PR}_{3}\right)_{2}\left(\mathrm{PR}_{3}=\right.$ $\left.\mathrm{P}-i-\mathrm{Pr}_{3}, \mathrm{PMe}-t-\mathrm{Bu}_{2}\right)$. Inorg. Chem. 1991, 30, 288-293. 